累そわとよそは

積れる結に㢳会社

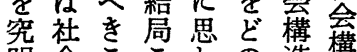

明会ととわの造造

す関とのれよの造

る係庄行るら分の

け形の関8 禁接

で式行連占てあ近

は的為のろ行る仕

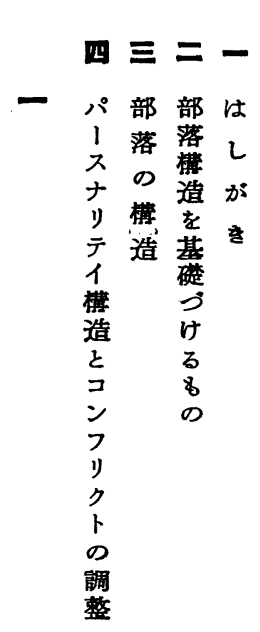

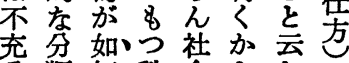

分類何秩会とわ

で汿市云れ社

あ平関的本 5 る会

面連先質と架学

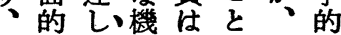

よスて、構行 $k$ そな

りタいに為なの調

動テる、他のる社查

的汃志関会研

にクとら連必構究

行に云なでず造の

為諸 5 らあしと論

の集ととり度理

連団とし、明何的

関のでて社瞙でな

の構あ \&会であ出

相成る。䦓造らり発

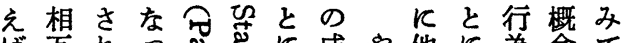

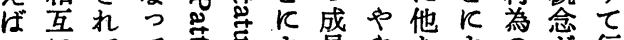

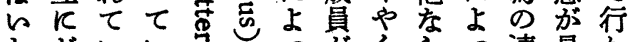

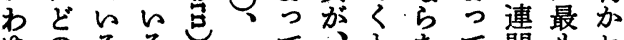

ゆのるるて関多ね

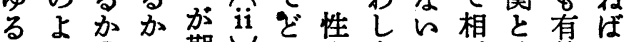

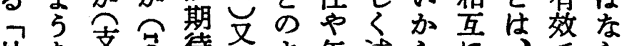

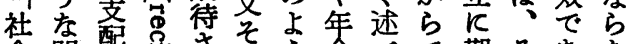
会関配总されう令望で期そあな

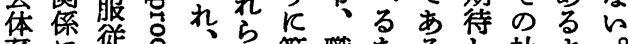
系に関导又の範職なる。社よ。

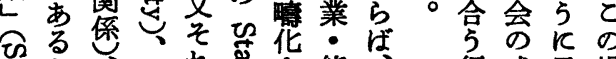

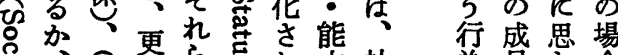
怘 更ら忘れ社為員わ合

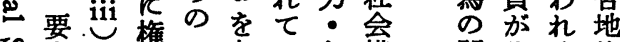

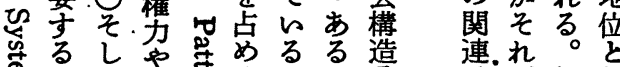

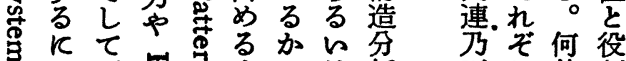
次更号品人は析至れ故割

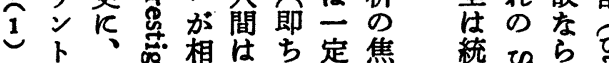

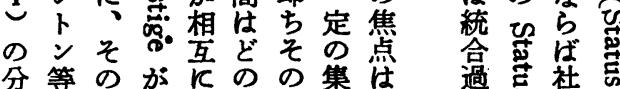

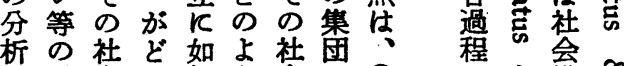
で言会の何 5 会

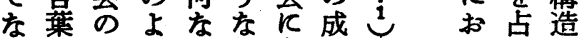

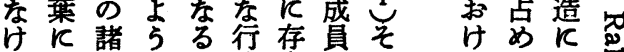

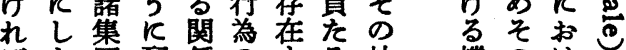
ばた田配係の守る社機のけ ながが置火型ると会構とるの

町

垢

浜

部

の

場<smiles>C[Te]</smiles>

藤

吉

桻 


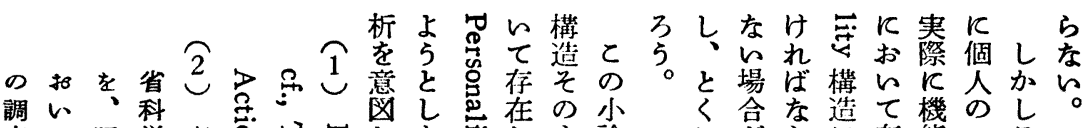

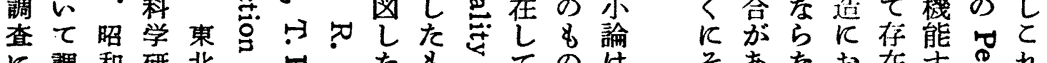

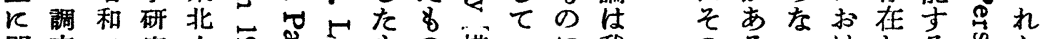

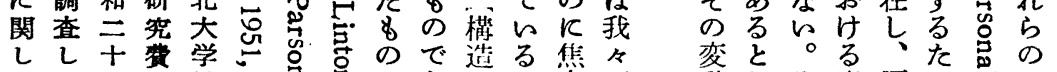

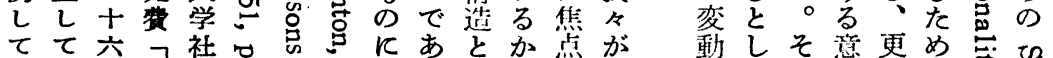

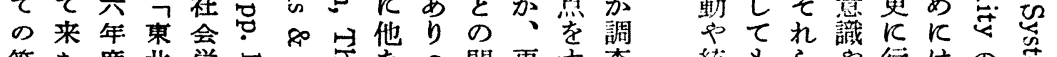

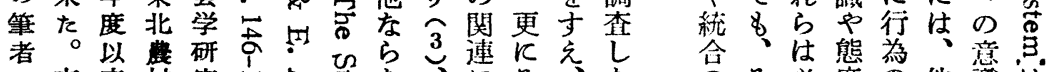
者本莱麓研究? 导

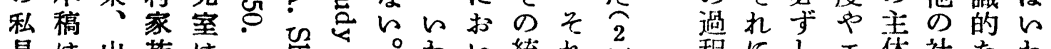

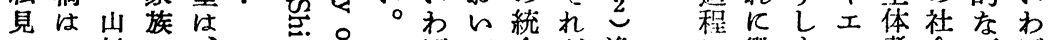

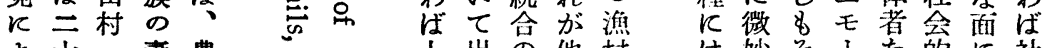
上十・妻農沓占出の他村妙々1た的飞社 る八水飞業号述莱程の影なのシる文比会

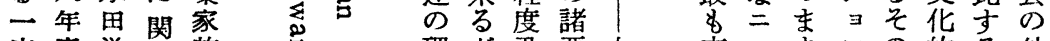
応度学す族点理だ要女支ュまンの的る外

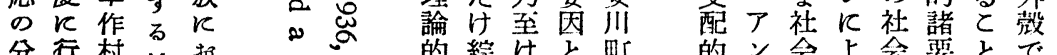
分行村社扔的綜在と町的ン会よ会留とで

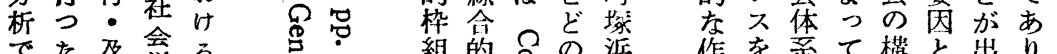

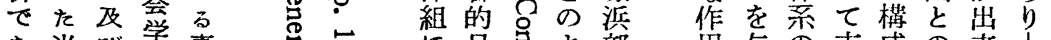

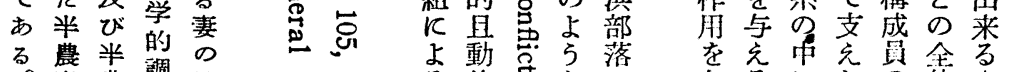

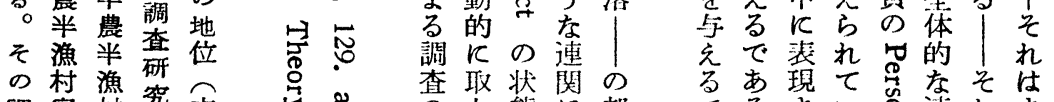

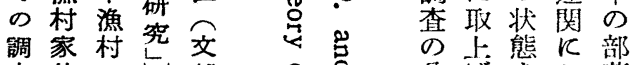
查族飞し部吕公分げをお落 でろさいす連れま あ5れな罚がさ

要合域亦会とわ约スっ結にに調に名取三か家調查の

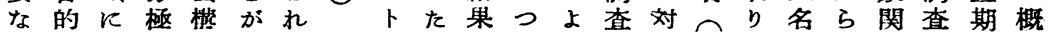

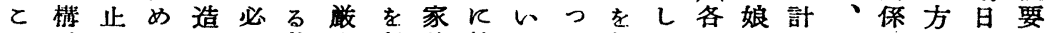
と造めて及要若密行族終てて行て世三人部等法はを で連る多びでなつ權つの部つ主带名四落飞は昭述 あ関よ様そあのるた造たイ落た势か、名飞つ、和心 る飞りでの

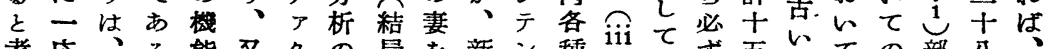
考応、る能又クの局索新ン種望調す五世ての部八、 えの-。は極夕た二選しシ集二簓二名代姑世洛年対

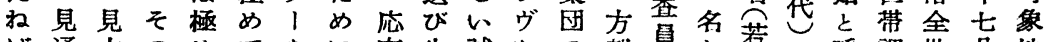
ば通大のめてをに有生試なの部員あ若・呼調算肙地 なしま意て有選は奻活み調權落面て世及ば查带三は

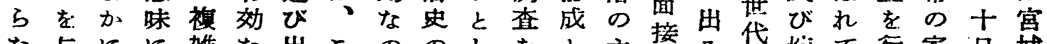

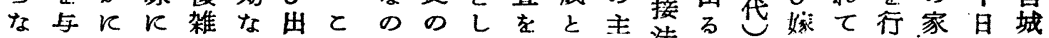

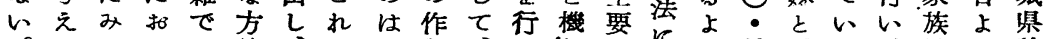

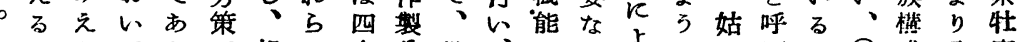
てたてりで相の名分世、・x名飞のばす とを、、あ互諸だ析代 がし分徒乃の要け及別话活妻んいて+同農末女

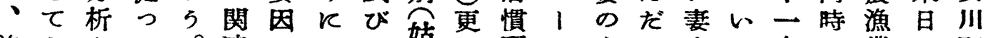
前ををて。連のな姑文習飞生が十石名飞業ま町

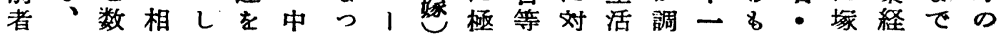
にを量関か数かてルなめ部す態查名の婿浜営の场

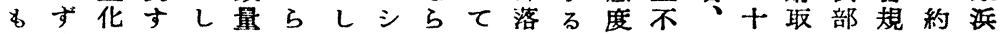
ま全可る現化重ま し 体能要実す要つッ $っ$ 充活取意三識名娘全

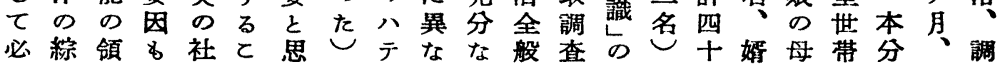


るす単

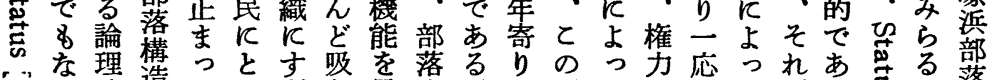

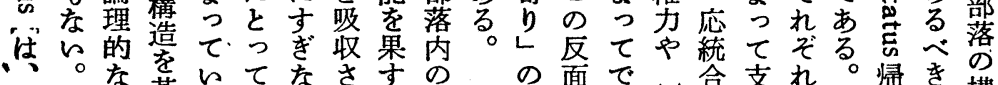

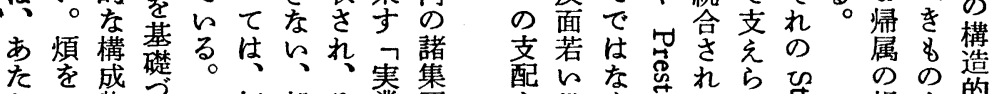

から物方何部そ業団

もとでけ等落の団の

幾わはる 直の他告中

何ず各接範のでで

学繰的の自年あ支

上返。関を令り配

のしして 心超集、的

点てかれやえ団同な

や云しら意长性族的

線えその味外集集の

がばれ構

一、自造

定部体面

を部団団は

の落との

空 構し 特

間造て性

的を存は

な加在

関たし \&

๖

$と$ 集 $儿$ 体落

と団子的吕

がへ実なの

係ちて ち

出の業機8

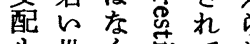

女世く㤐てれ高規を的

部垈の経のる

落無験配よ苦

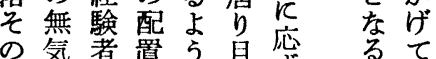

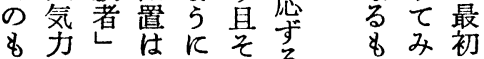

のやと文尔

の伝し同ら

女統て族れ苍.

権支矢理。莒

威配年や

のと寄経

なり済

品? ᄂ 的

号

来参団能の

とる与队

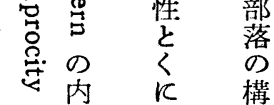

にづいろ

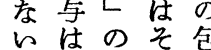

み。さ特

らしれ殊

ま部部飞的

るかて衣

は容年楿

よくるん

文居能

部落令的

落部吕京

活落方济

飞の決市

関定拜

すつ が る

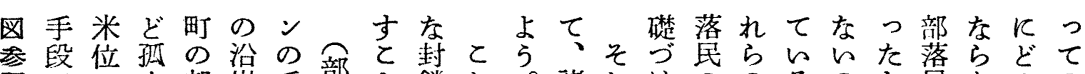
照での立部岸手落

䔦分及段落

又る岸たをを゙の封

新巡航四藮除三極封頡

聞航四落でて

ラ船严あそ島限

ジ齐がるのに定先

才密。大散に亦

才塚集塚部在㷌部

雑浜し浜分守因落

誌間て部はるすの

等だ落巡兰る封

のけるは航干。鎖

マを小船三塚性

ス二部山にの浜は

コ旦落でよ部部落何

ミ三去狭っ落落何

二復りら連ら属り

ケ夺、れ絡なす8

了る殆たさるるコ

シだん僅れが女ミ

ヨけどかる、川

ンで唯 一以漁町 二

とあ二五处港はケ

のるの○はを女ト

接 $○$ 交平殆な川

触地通方ん亦

と鎖れ

が性ら

出

来文諸

るれ条

と 件

構 の

造 中

的で

K

関 最

連 8

合基

的

てな

n 8

るの

経は

済

的

なの

諸 部

要 落

因 の

K. \&

म

ゲ極
諸れけののるのと民民なの 集故ら行的でし自らよみ 団飞れ為会あて体

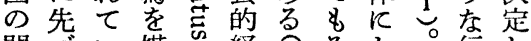
関亏゙ら媒経令々と行し 係々る介と済等れうし動得 及的飞的自てかをる びみし各諸所体は多期よ 部のるての桦でと、と待 5 落諸と、の件部したのしに 民条とと体の落てと相合、 の件がの亲上民意充互つそ 生と出部年の識赛にてれ 活の来落部展行に際期いぞ 構捙るの落開為のの待るれ 造関。社構さは弫行しかの を 通お

会造机云せ為合飞

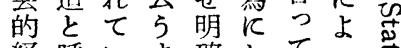

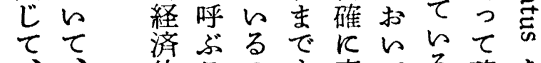
的と諸とでな表て主は確を 条にあくし之動さぬ 件しる彼得れのれる にた。等るに置る個

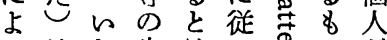
つはわ生はつ壱のが て、活限て穴飞相 基部之的怙他互 


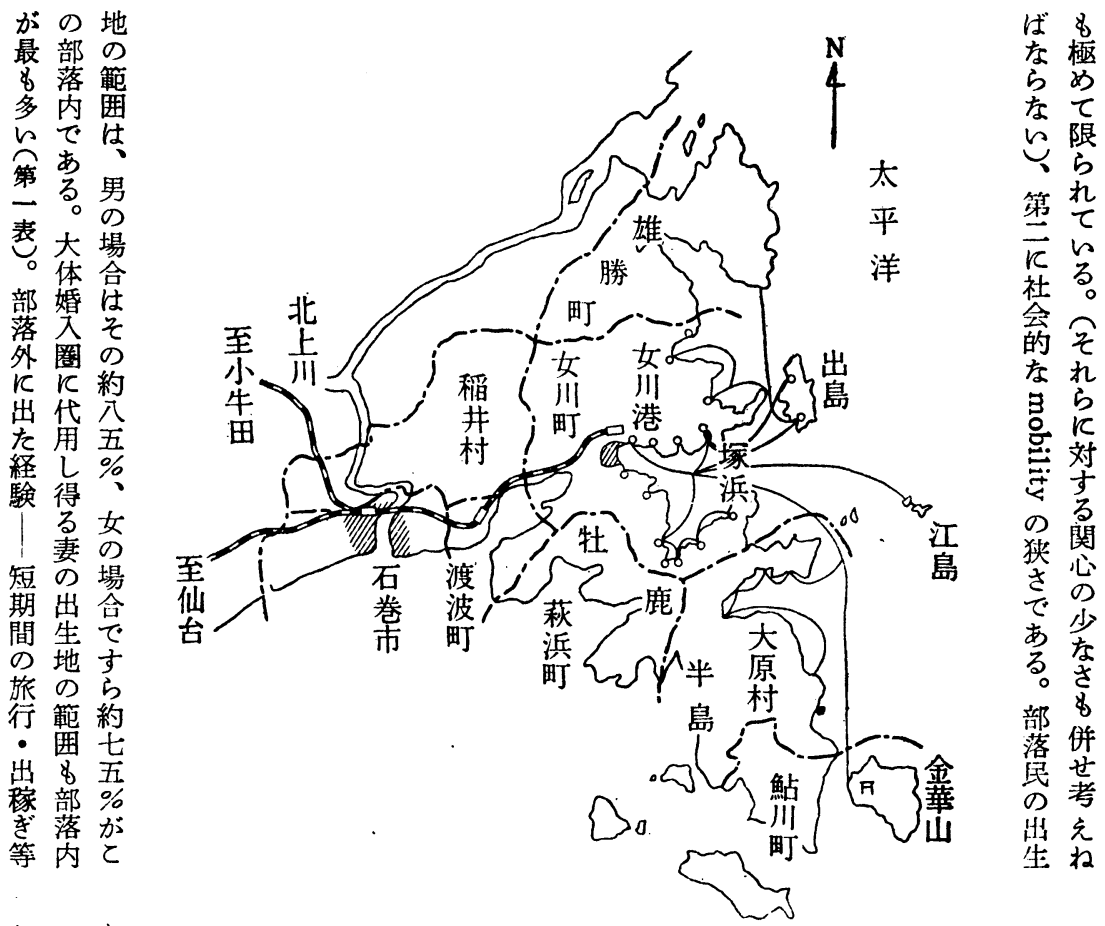


圭ま経あ埃

所た済

有戦 的

飞時な

何中階

等 $飞$ 層

の 漁 は

変船 殆

動

8 漁 ど

与民告

光の分

な徴 化

か角で

つをあ

た経る

験 第

そ ᄂ

名表

注少

意つ

寸た

へ

きと

で農

あ 地

万改

5 革

な
第 2 漁業種別漁獾高 （昭和 27 年度）

\begin{tabular}{|c|c|}
\hline 漁 業 種 類 & 漁 獾 高 \\
\hline 定 置 漁 業 & 59,950貫 \\
\hline 小型延 繩 渑 業 & 3,600 \\
\hline その他一本釣漁業 & 2,400 \\
\hline いけ抄ランプ網漁業 & 51,080 \\
\hline その他 雑漁業 & 17,262 \\
\hline 海＼cjkstart養 & な ᄂ \\
\hline 計 & 134,292 \\
\hline
\end{tabular}

なれ漁るめの漁 飯 $儿$ 業 第等雑業と 米大法第の魚形の 補部の夆採漁態部 充分下表取とは落

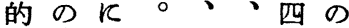
な漁おい第無卜生

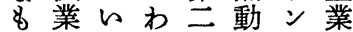
のがてば種力内構 で依安全漁の外造 し 存部く業小のは かし落岸権舟小大 なて占にに型ま に有へ属专船加

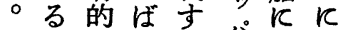
しのなりる站よ云 かで漁つ小絫るつ しあ場り型云夕て けれ利他と部か員生め族業小るにた定尔コ漁 れら用のす落8の産豊経と規のは零置飞漁業 ばのとたる全漁共消震営の模孛細網占! 点 な点なめぼ体業同費怤の有なっさなにるス農 らだつのかの自との場ウ機漁農さ地よウク業 なけて山り協体云生会工的業業加元る二イ主 らから林で力の5活合イなとはの漁小!網の

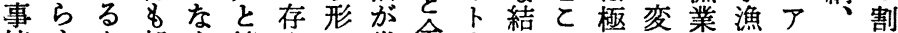

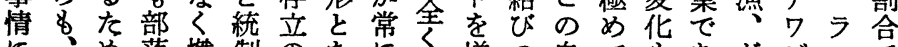

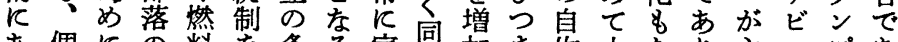
あ個にの料を条る家様加を作小なり主・ プあ

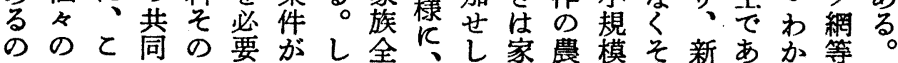

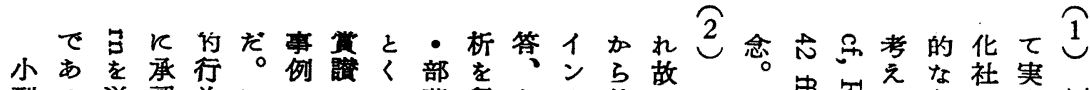

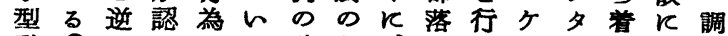
動 万人さ

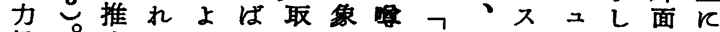

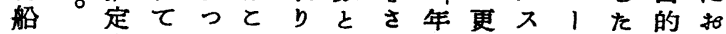

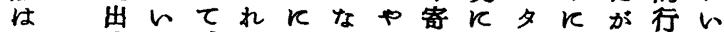
上来了、万意っ批り分デ対、為て く るず のをて難し校イす同のは 飞加导般逸注心或加教のる時分、 終 5 畐的脱いるは

[経営規摸別戸数]
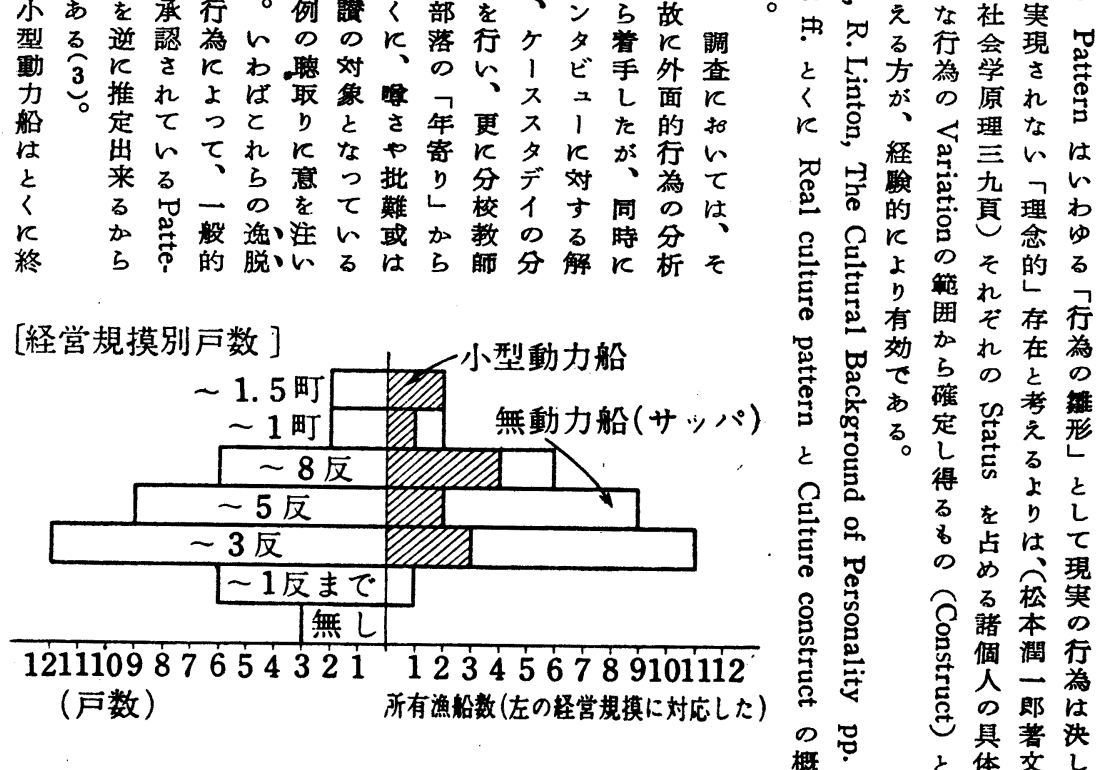
部正同 $こ$ 組 $と は ゙$ 的と

落反組生と織の新反そ諸 のよ合業にの部てはれ諸 占り几のす問落的女ら集 有女女組る題乞る川の団 的川川織。はの文町相性 な漁湾と触多文亩格 漁業南しれの区字の倠 場会部 て をが沿の ב分萨漁 ン割の業

トさ五組 口记部命 1て落壮 ル出で

す来編才

るた成 フ $\tau$ \& 1 のの昭 シ 部 和 落飞三儿 だ属十な 讨四女 のる年川 自と飞町 治共漁南 的 $k$ 業部 な、法溜 漁塚の深 業浜改協
なの、長塚関機 こ自は㴦係能 と治町あ概

机機行る観次

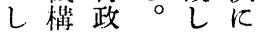
てのの町ょと 中下役 5 の 応芯機埸塚落 部あ满連浜に 落ると絡部存 内。 ᄂ 員落 在 のててはは壮 集との今云る 団で役な5主 には割おま琵 焦形よフでな 点式り区 \& 集 を的は舆な団 向店むしくの け行しと行性 る政乃呼政槄

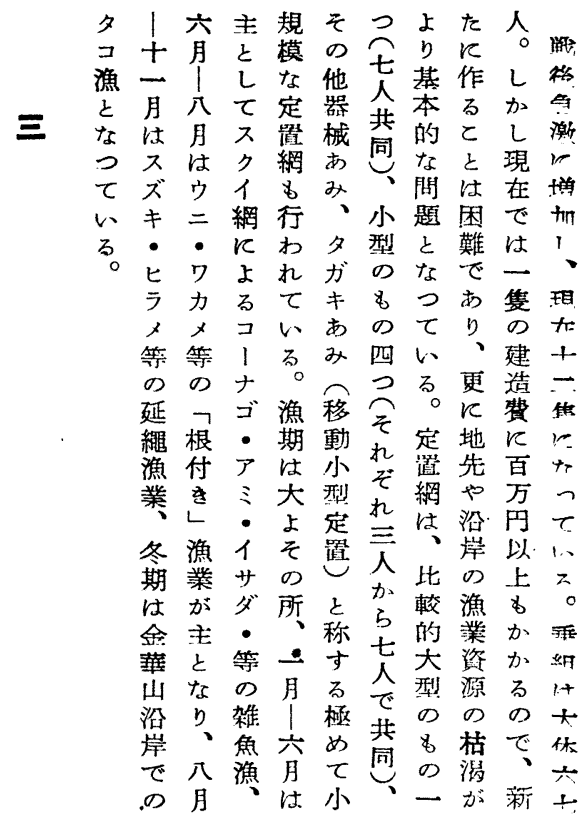

る資三をとの協部る成ど同織り集が部ししげ落縕 書の格千整呼与力落。と図部族と合ま落一たを的織 業で或五備ばべ、内即の参落関しいるそのお。受統へ

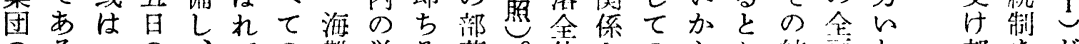
のるフの、ての難学々落 フ。一総若的機救働れに

才人会干た能助のはと

1 前在の主を交交。

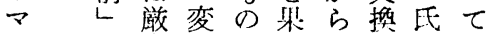

ルの蔽動でし風と神最

な规なはあて俗くの\&

構準儀あるいのに然重

成\&式つがる改家祀要

員、的た、集善屋合店

は す性現正な心建、集

八て格在九の身築学団

才とを年での校に

か れ\&で頃あ修屋へᄀ

らへちにかる镜植の寒

四の、至ら等替据業

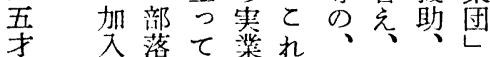

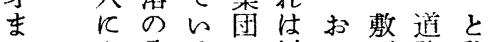

で上公ると以そ不路称

のつけ。改前ら浬排す

男ての每名はく搬水る

の決成年さ护部、路 \&

み定員旧れ約落葬のの

でさた允规約統候修が 体とのらか結沓わ とは䇰は、命をゆ 部をが

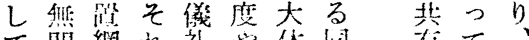
乙関絧礼や体间 の係の妾的阔五族 问で其㩆な族つ传 治あ间在坐との斩

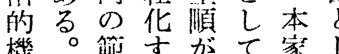
機。䇴索がて家し 的やと题機々 吸る、とと能の本 収飞小はさは分分 さ同型出扎極家家 れ族船来了ぬ飞好 てとのなくて区倸 的し乗的微分は るて組。尔翟吉形 との員たででる式 み集のと、あと的 て四筑充生り り 上的囲ば活、㤌 的機电漁的仏可存 の能、桠な事能在 では殆のかのでし あ殁ん一か時あこ前払の

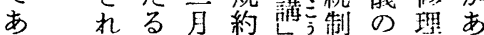

林的的 とるわ L て又る 一山ᄀ 定林口 の利阙 統用け 制のし のた 下为间 KK财 利部的 川落 ᄀ ᄂ 全 船 て 体 此 レでめ 万闹以 乙在 と林 死の等 前贽部 


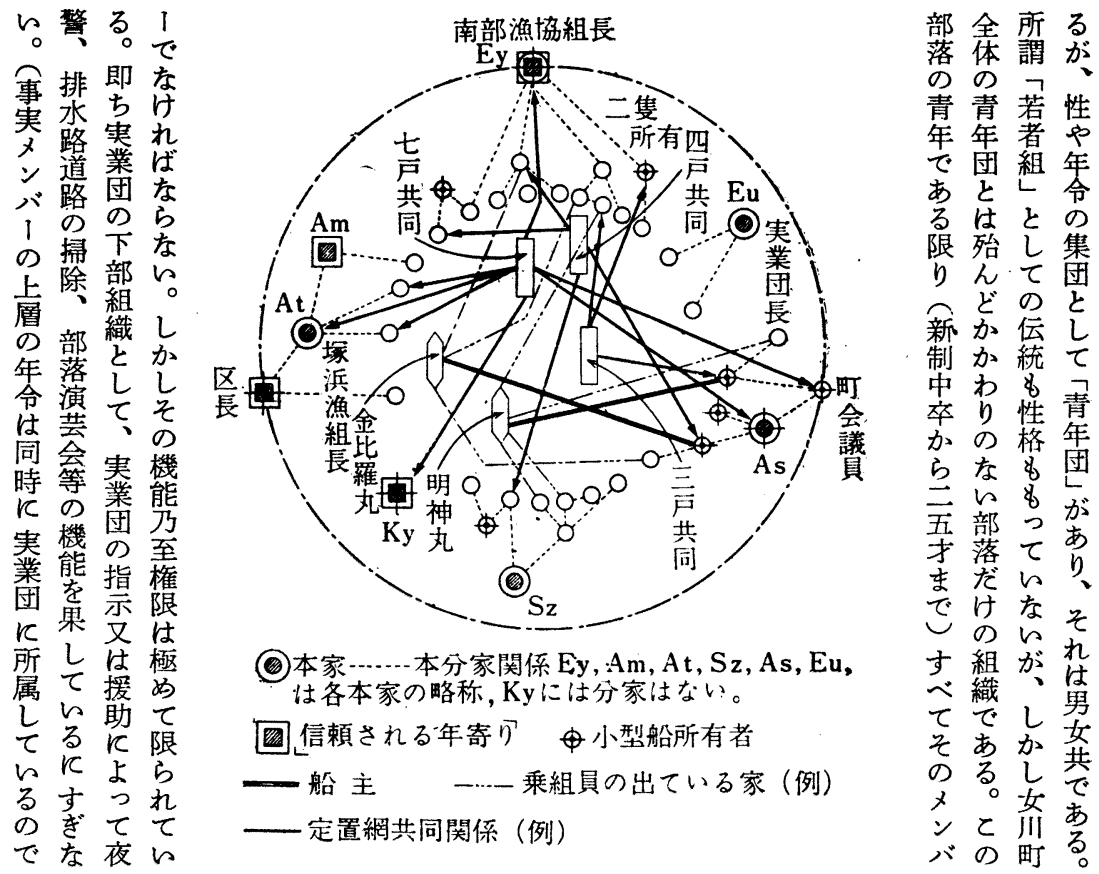

し漁性が年はでる

て業とあ令云あ地 は乞くげ、合る位 譩のにら家まと离立 義他年れ族で云 をの令てK\&公と役

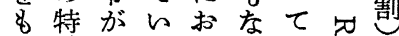
夺殊主るけ守字官社 准態方位しそ会 経力り、験置ばと取構 筷よ他こ職ば存占分 とるのの業片在て析 云階漁冢及导卞み.

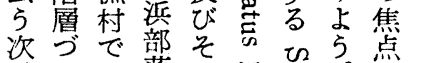
恣ずで落そ帰憵 。点

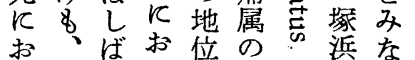
おこしい柆は究な゙ てのば特準極如得 年部重は殊とめ何る る 令落要前ななてに所 にでな前経る多封の よはる験も様鎖、 っそ要のとので的部 てれ因藏能はあな落 定体を臬如力、性と部存 さ定体荾く等と性と部存
の彼わず云の 由をし教部るしあ

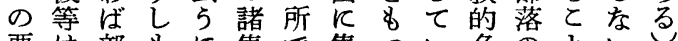
要は部8 $反$ 集で集つん名のとい

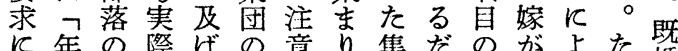
に年の際ばの意り集だのがよた既 忠寄つのず名守談団け下部うだ婚 実り年権、目へしがにに落てつ妇 反ட寄力実的き合な止持のそ女婦 しのりや業な事 5 守公の講人 た意し西団役は権以る

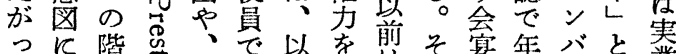

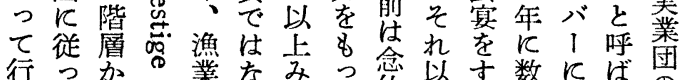

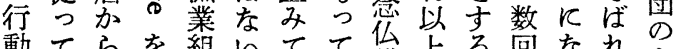
動てらを組いてて講上る回なれょ 寸、認\&合と来い講のと当るるる

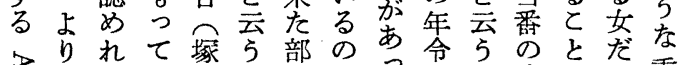

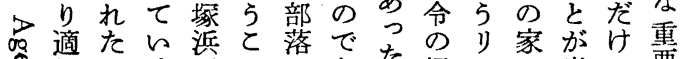

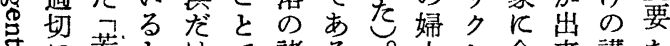
㳓とけで諸る。人と会来講な な云りはのあ集。しに合兰中機

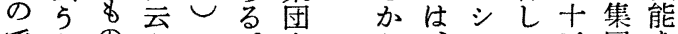
でなのえの劣し、ョコ团を あらし役青動 彼現ン安手がも

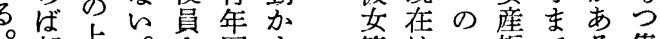
部㢳。さ団す等は一祈でる集 落愿彼えののは何機願、。団 そで等\&役は等能新結は のあ应員、組をのわ婚存 も者必はそ自織果宗ばす在 


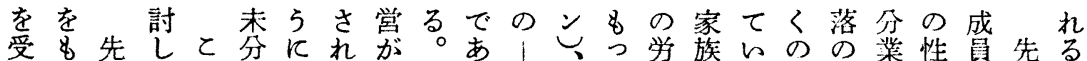

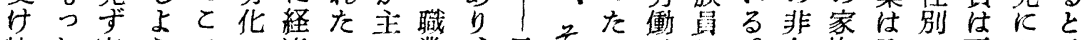

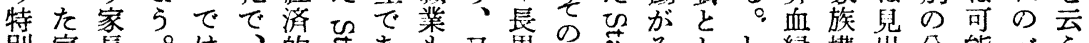

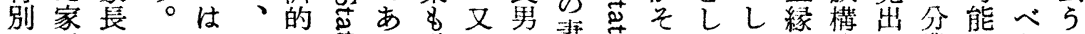

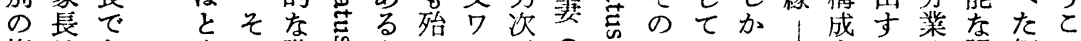

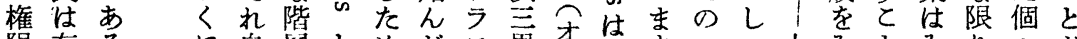

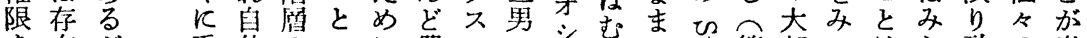
を在が重体の二に農への竞し的第部てはら殆の出

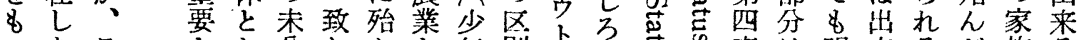

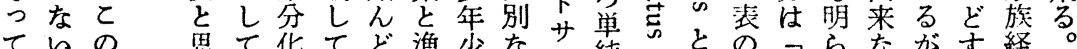
てらの思て货てど漁少な純のとのうらながす経。

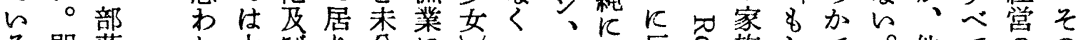

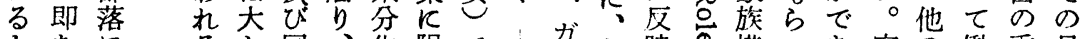

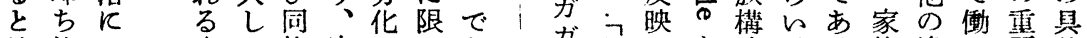
は他お家て族家でらあム分年しを成子る族漁ら要体 云の々族意集そ、れるス寄て決のし。経村て性的 え家て内義団の家て。コこりら定位を平営乃いの在

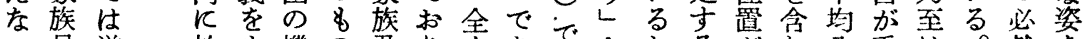
ら員览於も機の及りくあをとわる加む八重は。然を ○密けっ能階び、年りありけ\&之家・要都男的た

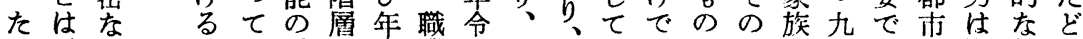
だ異ら位ら忘は令業にヨコのはでま形人あサ海結っ 要なわ置なしすに上よメ若家なもま態とるう、果て

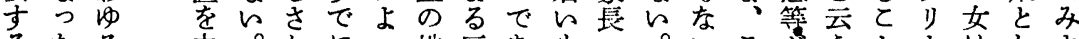

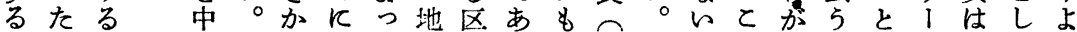

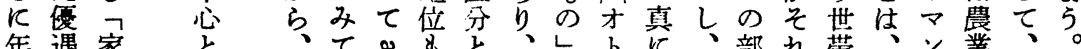

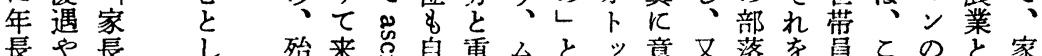

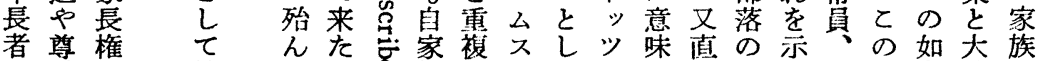

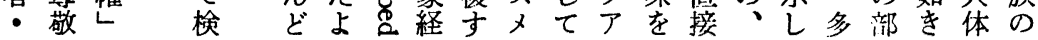

第 4 表 家 族 權成

\begin{tabular}{|c|c|c|c|c|c|c|c|c|c|c|c|c|c|c|c|c|c|c|c|c|c|}
\hline \multicolumn{3}{|c|}{ 直 倿 別 } & \multicolumn{5}{|c|}{ 直 } & \multicolumn{7}{|c|}{ 系 } & \multicolumn{3}{|c|}{ 傍 } & \multicolumn{2}{|l|}{ 系 } & \multicolumn{2}{|c|}{ その他 } \\
\hline 世 & & 代 & 0 & & & +1 & & + & 2 & +3 & -1 & & 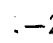 & -2 & 0 & & $+1+$ & +2 & -1 & 血 & 非 \\
\hline $\begin{array}{l}\text { 調 } \\
\text { 查 } \\
\text { 世带 } \\
\text { 数 }\end{array}$ & $\begin{array}{l}\text { 世 } \\
\text { 带 } \\
\text { 員 } \\
\text { 榕 } \\
\text { 数 }\end{array}$ & $\begin{array}{l}\text { 世 } \\
\text { 世带 } \\
\text { 平 } \\
\text { 均 }\end{array}$ & $\begin{array}{l}\text { 世 } \\
\text { 带 } \\
\text { 主 }\end{array}$ & $\mid \begin{array}{c}\text { 配 } \\
\text { 偶 } \\
\text { 者 }\end{array}$ & $\begin{array}{l}\text { 息 } \\
\text { 子 }\end{array}$ & 娘 & $\begin{array}{l}\text { 子 } \\
\text { の } \\
\text { 配 } \\
\text { 偶 } \\
\text { 者 }\end{array}$ & 孫 & $\begin{array}{c}\text { 啋 } \\
\text { 品 } \\
\text { 配 } \\
\text { 者 }\end{array}$ & $\begin{array}{l}\text { 兽 } \\
\text { 係 }\end{array}$ & 父 & 母 & 父 & 母 & 兄 & $\mid$\begin{tabular}{|l|} 
兄 \\
妹 \\
の \\
配 \\
偶 \\
者
\end{tabular} & 特 & $\begin{array}{c}\text { 蝟 } \\
\text { 姪 } \\
\text { の } \\
\text { 子 }\end{array}$ & $\begin{array}{l}\text { 伯 } \\
\text { 叔 } \\
\text { 父 } \\
\text { 母 }\end{array}$ & $\begin{array}{l}\text { 妻 } \\
\text { の } \\
\text { 近 } \\
\text { 親 }\end{array}$ & $\begin{array}{l}6 \\
b \\
W \\
\text { 子 }\end{array}$ \\
\hline 41 & 364 & 8.9 & 41 & 40 & 81 & 60 & 20 & 46 & 1 & 1 & 4 & 10 & 0 & & 23 & 1 & 14 & 0 & & 4 & 21 \\
\hline
\end{tabular}

（世带内夫㛿組数别）

\begin{tabular}{|c|c|c|c|c|}
\hline $\begin{array}{ll}\begin{array}{l}\text { 夫 } \\
\text { 組 }\end{array} & \text { 数 }\end{array}$ & 0 & 1 & 2 & 3 \\
\hline 実 数 & 0 & 18 & 23 & 0 \\
\hline$\%$ & 0 & 43. & 56.1 & \\
\hline
\end{tabular}

(世带員数别)

\begin{tabular}{|c|c|c|c|c|c|c|c|c|c|c|c|c|c|c|c|c|}
\hline $\begin{array}{l}\text { 数 } \\
\text { 員 } \\
\end{array}$ & 1 & 2 & 3 & 4 & 5 & 6 & 7 & 8 & 9 & 10 & 11 & 12 & 13 & 14 & 15 & 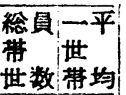 \\
\hline 実 & 0 & 1 & 0 & 3 & 2 & 3 & 2 & 5 & 6 & 6 & 5 & 5 & 3 & 0 & 0 & $364 \mid 8.9$ \\
\hline
\end{tabular}

(家族形態別)

\begin{tabular}{|c|c|c|c|c|}
\hline 家族形態 & $\begin{array}{l}\text { 㨁系血 } \\
\text { 族のみ }\end{array}$ & \begin{tabular}{|l|} 
直采血族 \\
+ +傍监族
\end{tabular} & $\begin{array}{l}\text { 㨁系血族 } \\
\text { 十韭血緣 }\end{array}$ & $\begin{array}{l}\text { 值系十傍系 } \\
\text { 十非血緣 }\end{array}$ \\
\hline 実 数 & 24 & 6 & 10 & 1 \\
\hline$\%$ & 58.5 & 14.6 & 24.5 & 2.4 \\
\hline
\end{tabular}


いる業生権い種た合海一出コいにらるげ者いけで年 \&奏労業をるふると般次る座は表主となとがでは寄 の力㗢の\&。のと同仕飞飞のしなわ、云らし、みなり

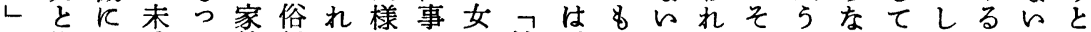
と権お分て計信ら反やの姑殆必しるの条らの林はし

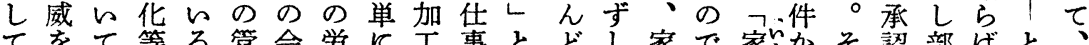
てをて等る管会学に右とどし家で家かそ認部代と

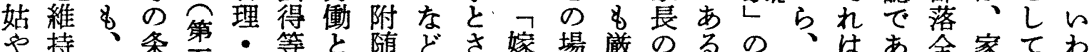
家し持家件吾農の等々随どさ嫁場跾のる。代又経る体長の壮

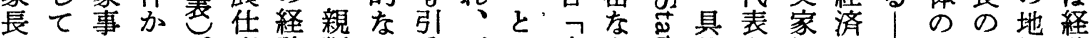
にい二ら。事験類\&受更は家\&志体著族的 8 位験 命る切、にのとやのけ反ど長の心的とがに反つ芯が者 ぜかや依わ割知若にね、5 でのにし部はよ慣志存と らの部然ば振識开止ばのでではシ云て落生う習の新し れ如落と部りかの交なりああなン充の構業て的はるて

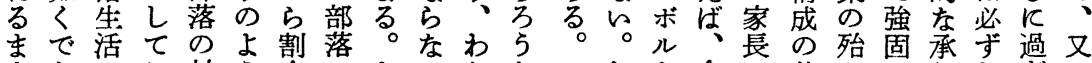

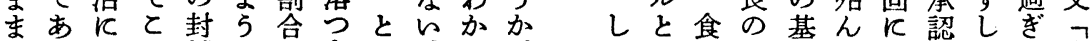

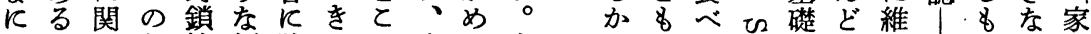

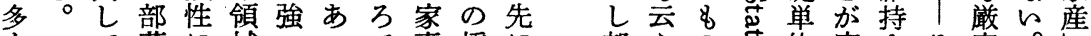
く一て落に域ららで事採反 の方\& $\ltimes$ よで地の子学取の 自嫁、おるは位処姑㗢、 然は嫁い生家を理しは魚た

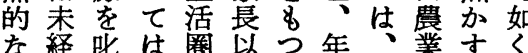
な感駼品は圈以つ年永業すく 箐者指姑狭至行年族乾農 さ筫はさ登っ事にの燥業

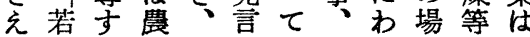

部えの芯位家さそ密。し 落るやと族れれととの のフ衣とな経ては確の管 フに服吃っ営に年定よ理 つろに官てを寄さら者 をり特の主とりれ反 あし別がるとみ即て家 らのの外事しなちは族所 レつち部、情てけ経ら内有 にヨが的かられ験なだ者

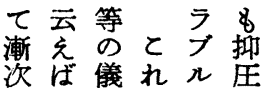
的式ら充 反若化の生

移 6 \& 家活 苦 行世み長を痛 寸代号権続 るとれやけた の古な辛てえ がらら婦らし 常世し権るの で代、のづ あの又移後な る、そ讓述が 。家のは、吕 乙族 時 加生期 そ期

し活8れ

そ的自

れ対定体 は兄允架

実果的既 貿すなで 的役学あ な割。る 労衣概た 倒比括 め と例的 $\mathrm{K}$ 平 $L K$ 何

葛 5 家族員の役割

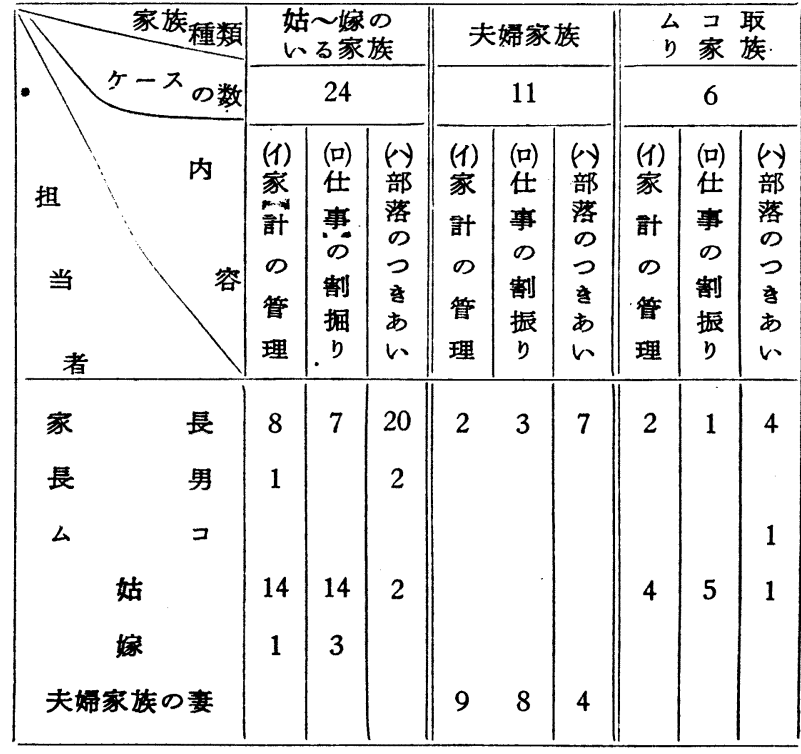




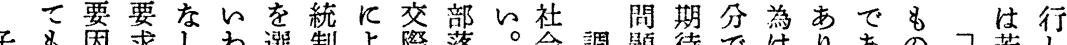
供部で求しわ非制よ際落。会調題待ではり、望若若し

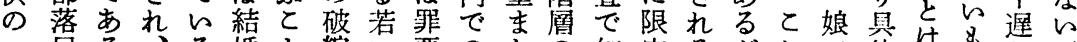

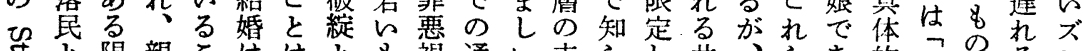

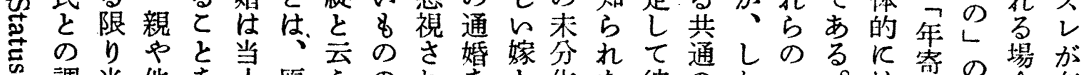

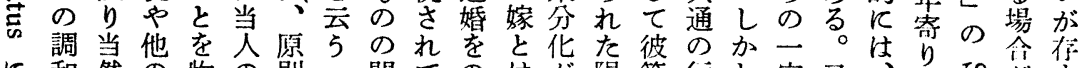

に和然の物の則二間てのはが限等行し定又、乞导がす

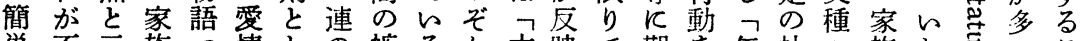
単不云族つ情しの婶るん丈映で期を年社々族わ忍らこ に可え員てとて事妬。で夫しは待胃寄会の内ばと。・と 触久るとい云親情の部々でて、出り集部のと行暚は

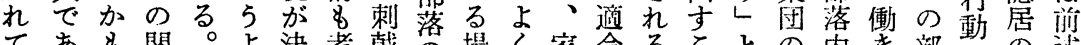
てあ\&関よよ決考戟の場く家令るととの内き部のの述

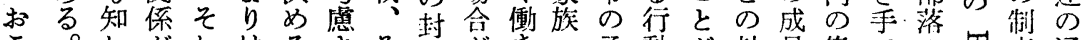

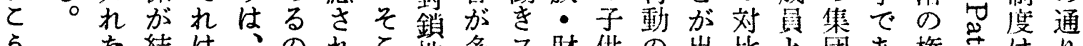

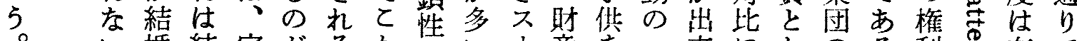

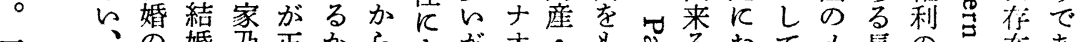

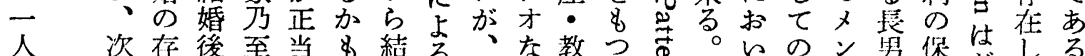

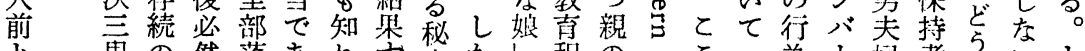

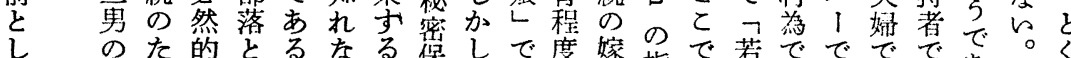

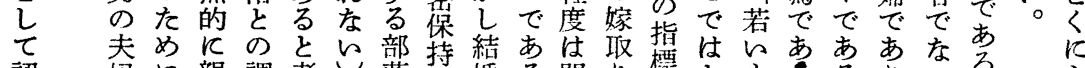

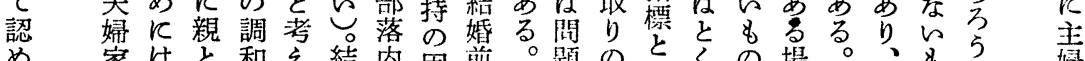

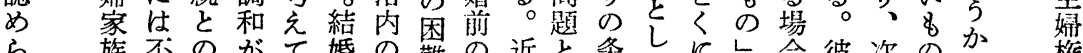

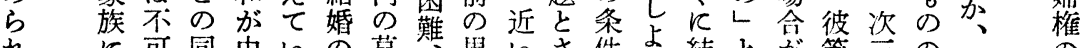

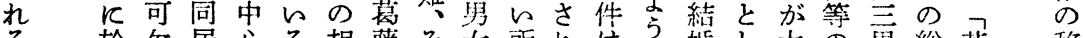

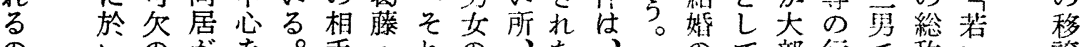

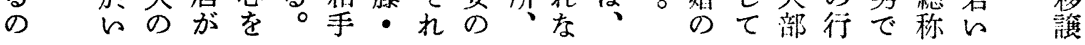

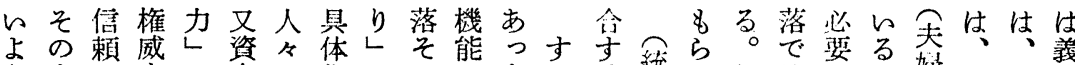

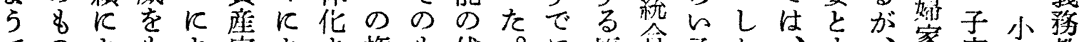
でのよ\&よ家よさ権\&代。に原含子尒、专族守学教

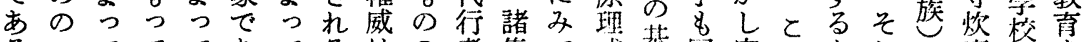
るってててあてるはの者集て或㖫同奏のたれれ事のを

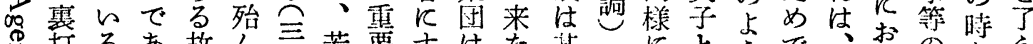

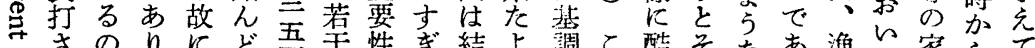

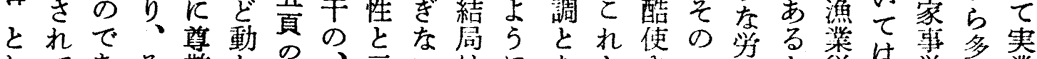

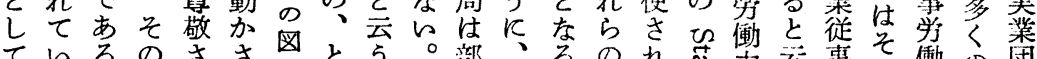

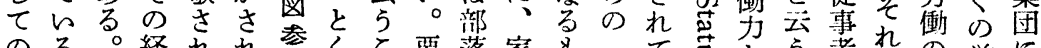

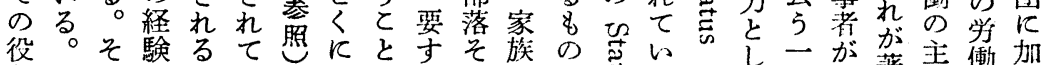

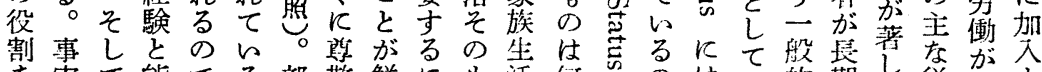
を奏て能でる部敬鮮に\&活何にのはの的期し従期す 忠彼々力は。落さ明フのにでとで何子なの称る

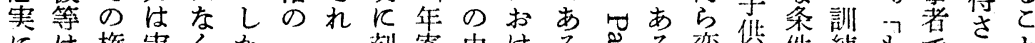

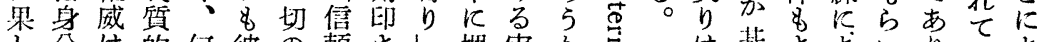

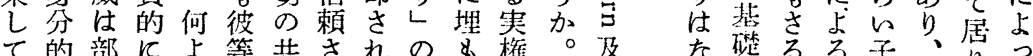

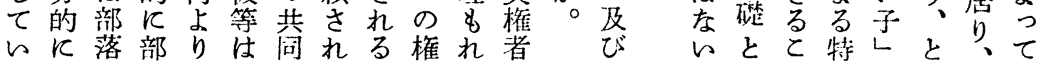
る\&民落\&身生る。威或は諸崖を殊がく市で

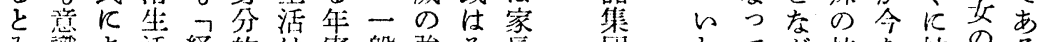
み識よ活経的は㝒般強そ辰団わてが技な㚲子る

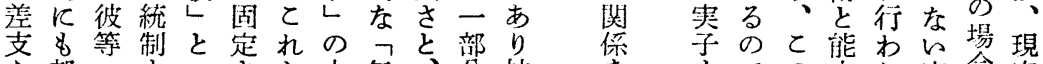

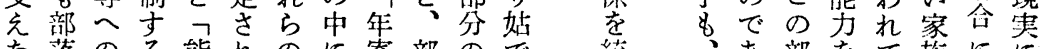
な落のる能れのに寄部ので統、あ部をて族にに 


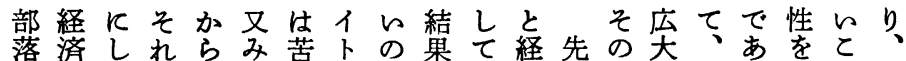

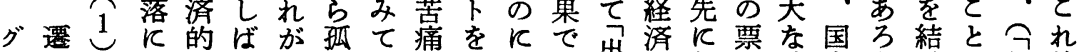
リ $K$ 止社し 伝立来で增\&\&出的部は社会 5 果 $飞$ 年等 船す伝ま会ば統したあ加かあ㮃条落、会議。すな寄の 拘統る的述のてょりせかるさ件構保飞員町るるる事

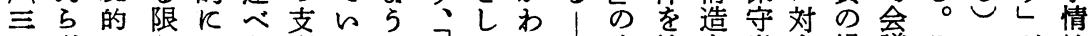
十すにりとた配るに若めら少検を党す場議そ一がは 馬存部不のととと多台々ずをな討基のる合員の般自反

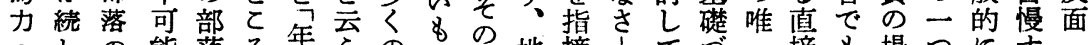

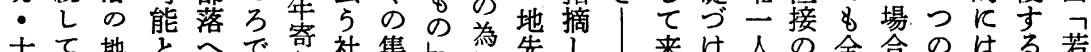
十て地とへで奇社集し為先し 来け人の全合のはる若 九い先なのあり会団は宗漁得そたるの関部反表伝如い 卜るのう依るの的と極完業るれ。諸候心投は現統くも ンる海て存。権な人ぬ全と。はと条補は票部をのよの のをいから威条聞て高即個れ件者殆は落完くし

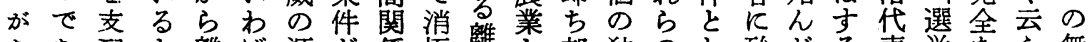
ああ配と離ば源が係極树と部独のし殆どる表挙なえ無 りるし云れ個泉、が的村の落立諸てん限がとしるば気 、。てわるとと個、なは結内の条、どらっしの支敬力

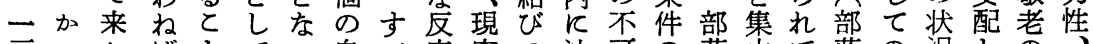
戸つたばとてつ自へ応実つ沖可の落中て落の況との 一て子ながのて闺てしのを合能直のしいを性に、念年 株场のら前独らの部か直は漁性接もてる超格探個が奇 の浜でな提立る余落示接家業ののついにえかるの厚り 平漁、々でのと地内しの族の表端極るか加らと独く 等業漁。あたとをとて問経経現的端。かと問と立、の

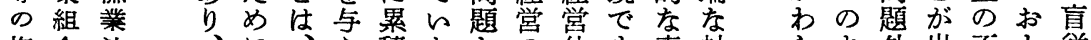
権合法、に方積なとの体8表封方よ外出不々従

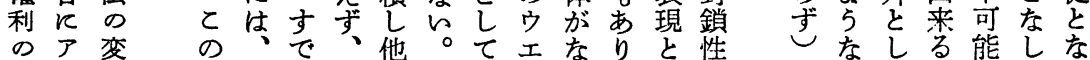
の 変

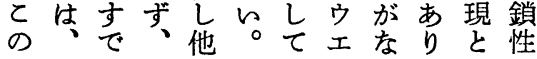

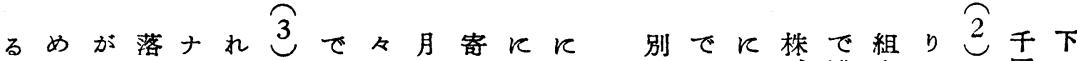

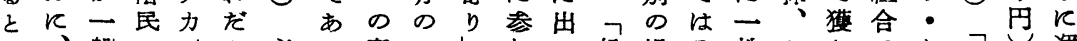

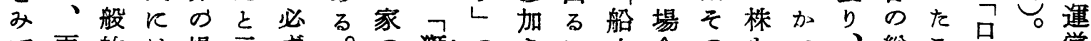

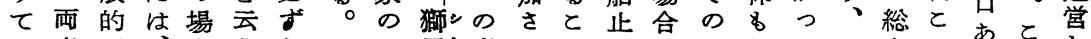

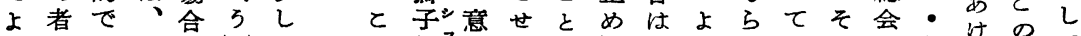

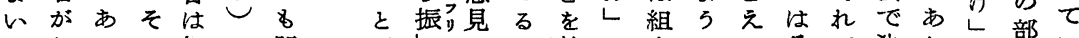

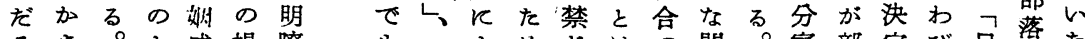
ろさ。よ威場瞭泉よめじはの間。家部定びロ洛た ろなと 3 関合で部祭つの烈、承題全し落す等どにが り 名な保はは ああ用を、な つれ語指同い て のす族 が の区と関 、 本部別8 係 シ 家で知 5 あ ル

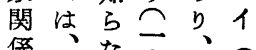
你、部い古工親 云部い落老 エ 親 5 内 シ 談 ル 数 形通ン。1 チ が婚セしへワ とのキか縁力 与累とし 類 $レ$

机積 云一

ての $ら$ 般 エ地 いたの部ン 分

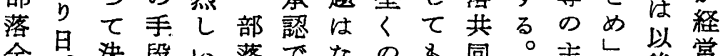
全旦決段い落ではの櫵いつ同○忘し後営 の部すあ定全謢い他年費口乞対個困 援落るる競のと只所間角あて象経難

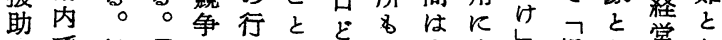
をで船区を事がめの半充し根な営な

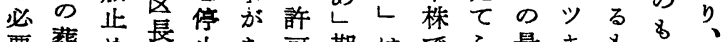

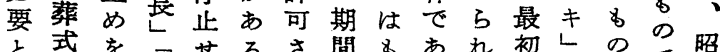

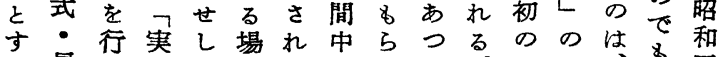
る屋 5 業め合るでえた。目るす。四 と根行団て过すなが組はの5㚏年 認替事の全全 ᄀい現合部でに型に

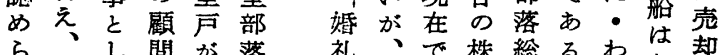

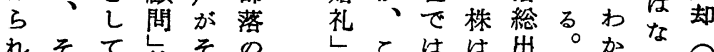

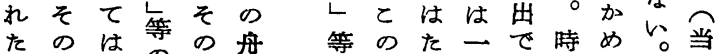
場他、の行がの部 $゙$ 戸共期 ・・時 合個正年事漁特落ち一同はの八 
条ナれ為会

件リカてに構基

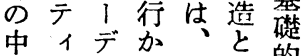

で楆々ね更の的

主造ナばにダに

要の1なとイス

な特へらのナ元

8性?な部、尗

の穴落ッ落市

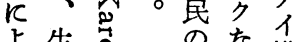

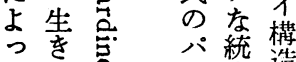

てて怘 1 合造

決行 スの概

(20)

妥件る各源な民全日事 $\stackrel{4}{\sqcup}$ ををし

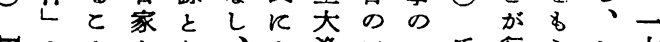

四上ををな、漁二一民行

上りでまるそつし昼つ神わいンフ

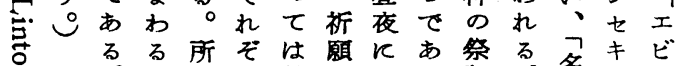

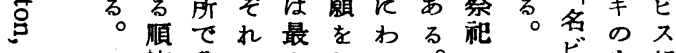

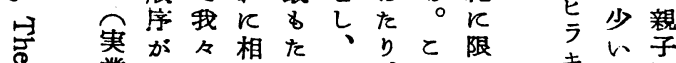

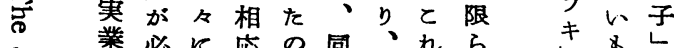

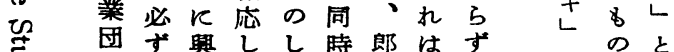

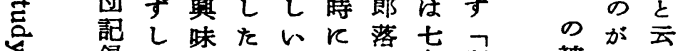

○録名寄行民内人獅”被部了

定くがナ程 概

さた指归度念

れめ摘 テ乃

且適て 楎至し

そ応的造そし

れしる 爪のの

他けく䓃れ

のれ、分セら

さば人析スの

まな間のを諸

ざのメみ条

まなパ スて件

のら、を行と

適諸 久 入く社

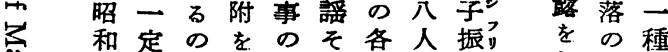

ま一世はす一の家のりりし有の

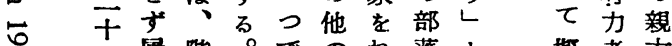

岕四展階。での落と擬者方

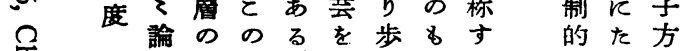

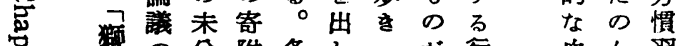

子小分附各し兄方行血 2 習

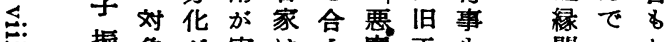

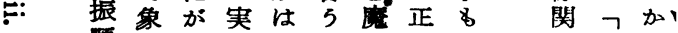

包順と業酒と払月実保エす

㮰映団食云いの業をビか、

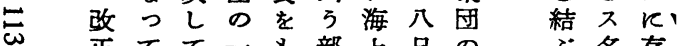

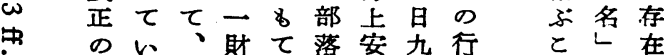

独極りリれけ構落・コらら化合ば積しするパなと応 断めわ故る力造全家ンはわさ壳、極かても1 只の的

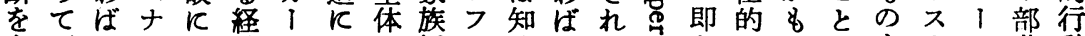

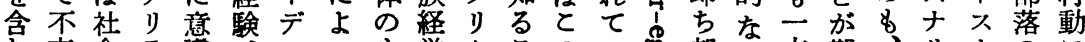

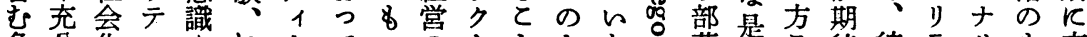

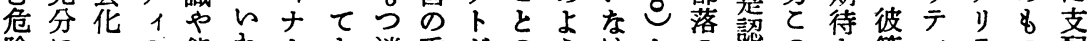

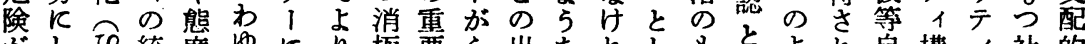

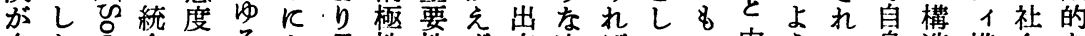

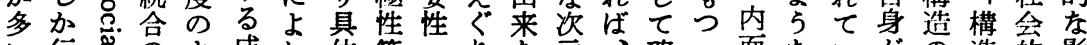

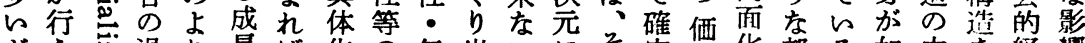
が 5 心過り長ば华の年出

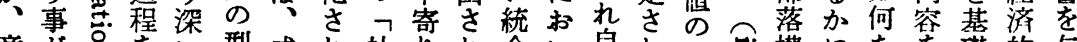

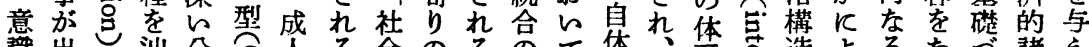

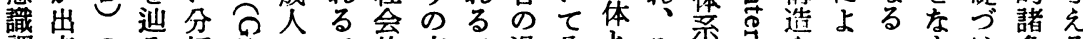

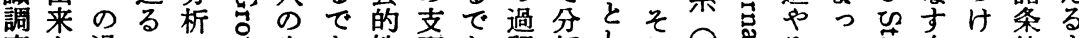

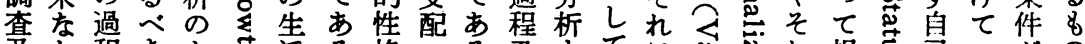

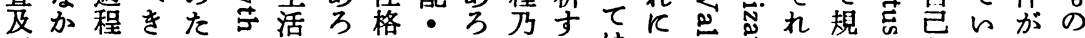
ひっのでめ包態5。個5。至る在よ壳の蕉を評る結と

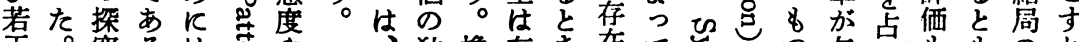

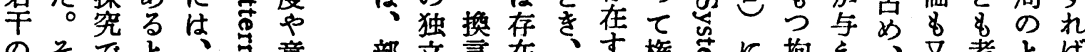

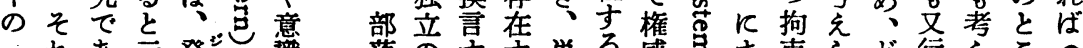

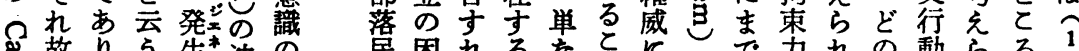

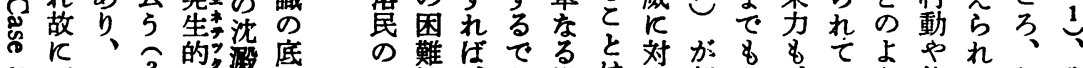

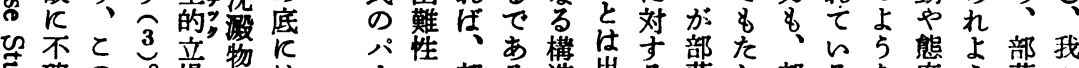
志確の晹物は注部乃造出る落ら部るな度5落々

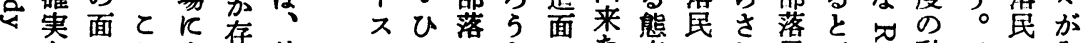
の奇れ立在幼 結推調らつ货時りて封と分にが超なの爷機個基て

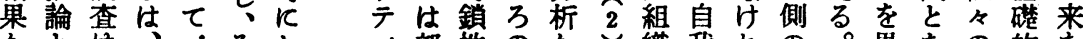

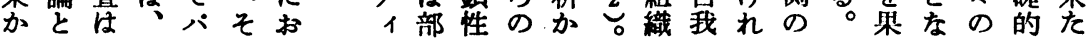




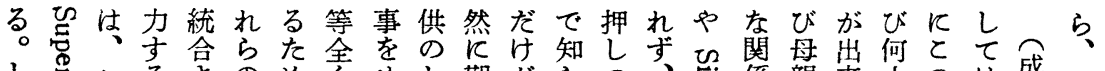

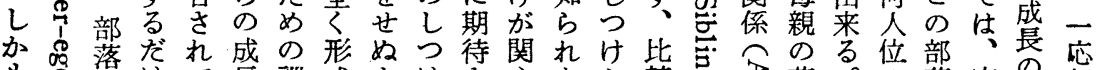

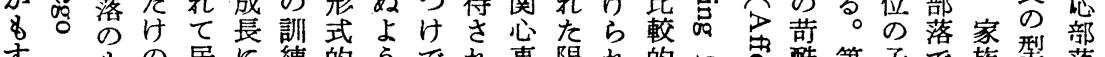

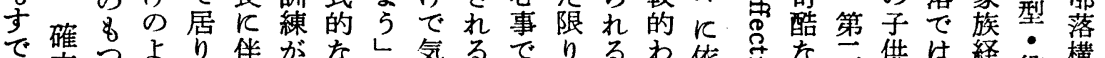

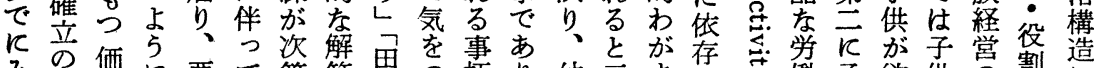

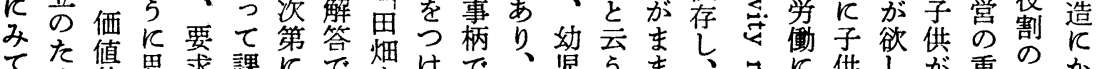

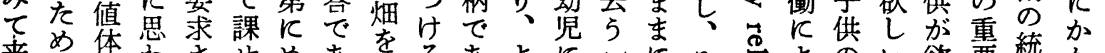

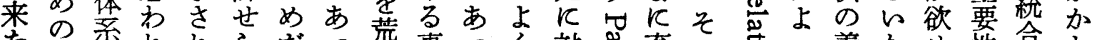

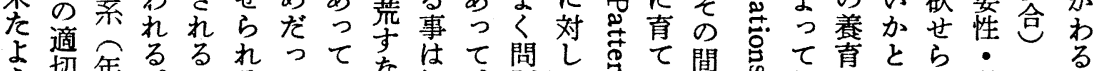

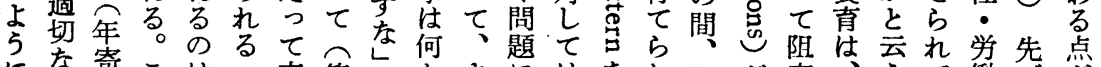

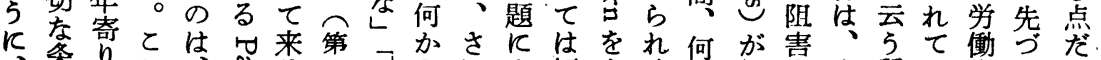

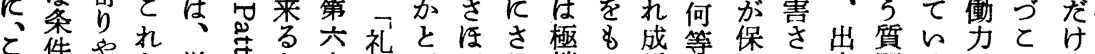

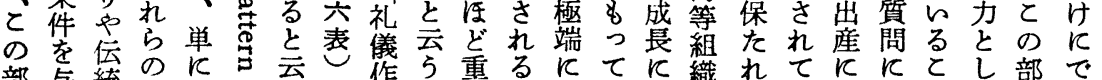

部与統の

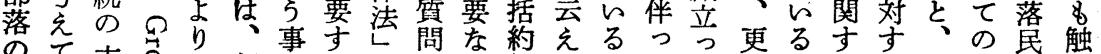

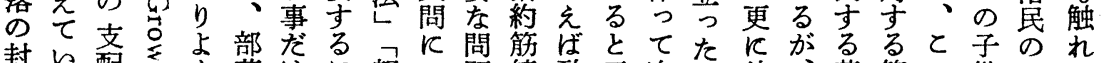

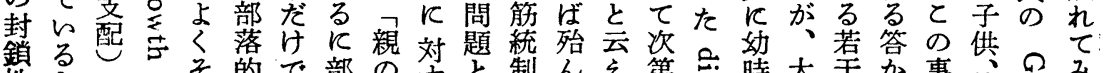

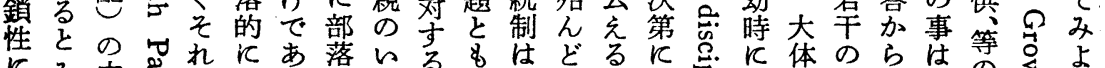

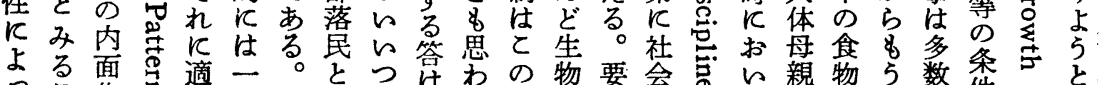

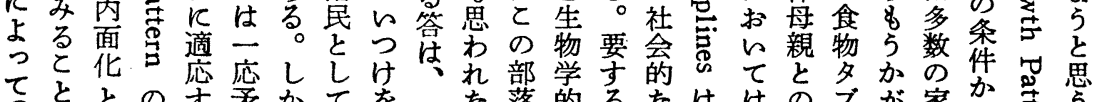

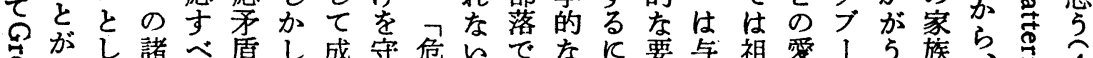

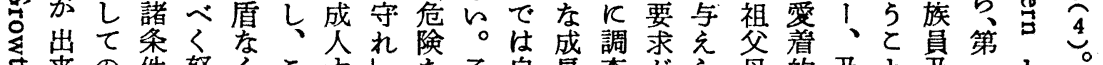

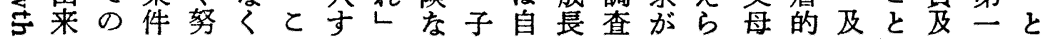

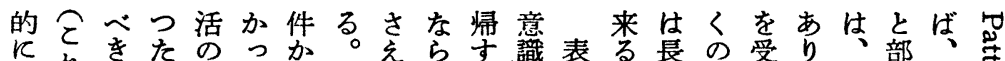

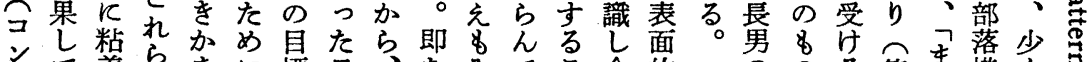
ンて粘ら吕め目たら即的んるし面

フそ着の竞標晃封方みでと合的

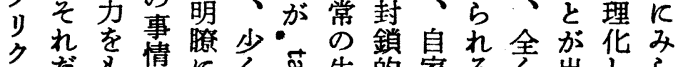

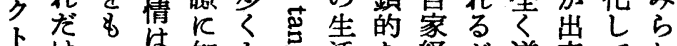

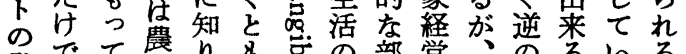

発でて霜り亭の部営、のるいる

辇あ表社得ひ。瞬落・そ意かる種

生ろわ社るけで間の瞬れ識の通积

5 れ会とをあ々生間8即よりの

てかて場会取っ々活的単古5 K不

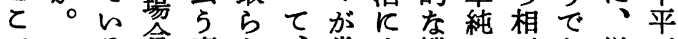

でる合事な、常止機晳互あ単不

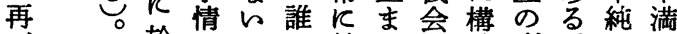

び於かたが競る主造烈。には

構元らぬ自争限努的公更個多

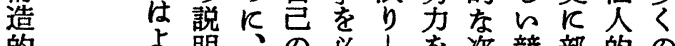

的占明、の必索次競部的の

なりが自競要必元争落な場

面楥 つ色争事要でや努合

に慢々怔者実々理或の力

戻でよ何で、止す解は緊の彼

ら あ5をあしまる出粗密不等

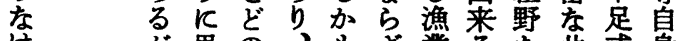

け架思の、8さ業るな共或身

れるわょそ占るとょ利同はが

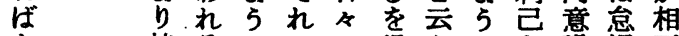

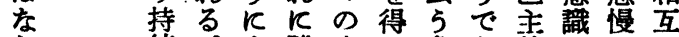

5

続。勝生な条あ義と禹慢

ののる第志構く

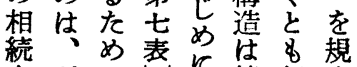

を財飞等働統部定

絶座等又憅合落导

対は驿艺染る

視つの若机の条

寸的理的先生件

る, 由嫁め居活 と

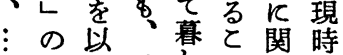

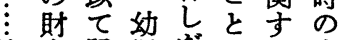

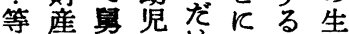

↔即姑のけ限活

反ち と 世思るり、条

映家同のら事彼飞

先痤居たな寒等大

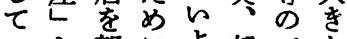

いと望飞よ部パな

るしみ5落 1 差

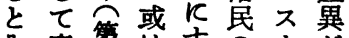

み意第はすのナが

る識八任る生りな

と位表事と活 テ

が相又指し目構す

出続多迹で標造れ 
第 6 表 子供のしつけで気をつけること

\begin{tabular}{|c|c|c|c|c|c|c|}
\hline & \multicolumn{2}{|c|}{ 古い世代 } & \multicolumn{2}{|c|}{ 若、世代 } & \multirow{2}{*}{$\mathrm{C}$} & \multirow{2}{*}{ 計 } \\
\hline & A & (A) & $\mathrm{B}$ & (B) & & \\
\hline あぶないてとをせぬようと & 1 & 1 & 3 & 1 & 3 & 9 \\
\hline 親のいいつけを守るよう & & & 2 & & 3 & 5 \\
\hline 田畑を荒さす，海に注意 & 2 & & 1 & & & 3 \\
\hline 仕事の仕方 & 2 & 1 & 1 & & 2 & 6 \\
\hline 男らしく，女らしく礼義作法を教える & 3 & 1 & & & 1 & 5 \\
\hline 健康と注意する & 1 & & 2 & 1 & & 4 \\
\hline
\end{tabular}

第 7 慕しのめあて

\begin{tabular}{|c|c|c|c|c|c|c|}
\hline & \multicolumn{2}{|c|}{ 古い世代 } & \multicolumn{2}{|c|}{ 若いせ代 } & \multirow{2}{*}{ C } & \multirow{2}{*}{ 計 } \\
\hline & A & (A) & $B$ & $(\mathrm{~B})$ & & \\
\hline $\begin{array}{l}\text { まじめと㗢いてせめて暮しだけは困らな } \\
\text { いよらとすると }\end{array}$ & 5 & 2 & 6 & 3 & 3 & 19 \\
\hline $\begin{array}{l}\text { 家に財産をふゃすよろに一所けんめいに } \\
\text { 㗢くとを }\end{array}$ & 1 & 1 & 3 & & 4 & 9 \\
\hline 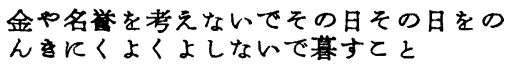 & 2 & & & & 1 & 3 \\
\hline $\begin{array}{l}\text { 世間の人はどろあつてす自分はどてまて } \\
\text { も正しく基すとと }\end{array}$ & 1 & & & & 1 & 2 \\
\hline $\begin{array}{l}\text { 他人からとやかく云われないよにまじめ } \\
\text { と㫷すとと }\end{array}$ & 1 & & 3 & & 2 & 6 \\
\hline $\begin{array}{l}\text { 自分のことを考えないで世の中のために } \\
\text { すへてをささげて㫷すとと }\end{array}$ & & & & & & 0 \\
\hline 不 $\cdot$ 明 & 1 & & & & & 1 \\
\hline
\end{tabular}

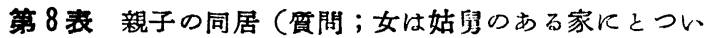
だ方がよいか、それとも夫婦だけがよいか）

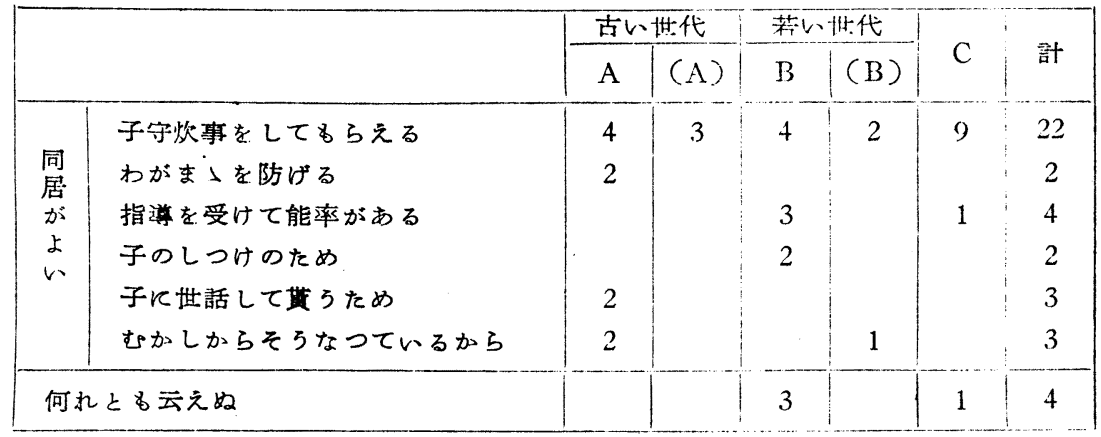

註 古い世代……A姑，（A）ムコ取り娘の拇

若い世代……B嫁，（B）ムコ取り娘

$\mathrm{C}$ 姑のない㤗 


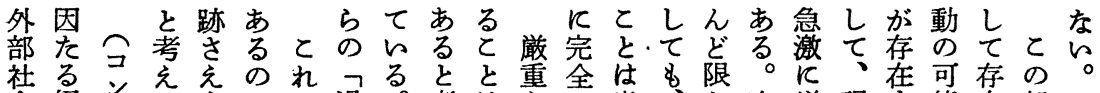

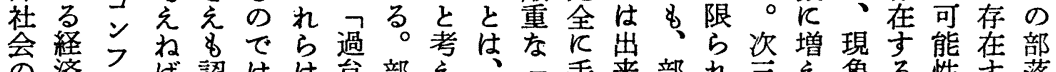
の済りば認はは急部え、、手来部れ言え象る性主落

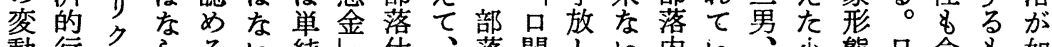

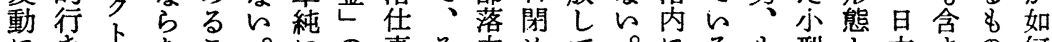

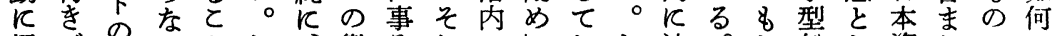
帰亏゙調占と何徵之れのししし沖。ら船し資れでに 因ま整。吕故戦収の盆禁まか合農ら方て本てな封 乙り整出な後\&他大笨制5\&漁村子漁は主いい鎖 ては来らの主の目者に出家業のの場、義なと的 居、云なば新た奏に老箱族の場処が第全らとで

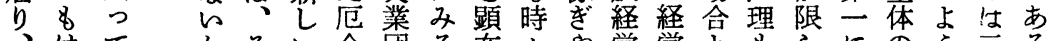

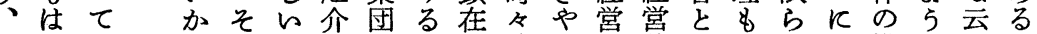

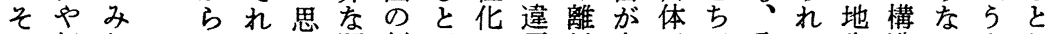
の部れでら想問行云さ反村大がが分て先造とまし 解落ばあは題事5せ者もをなっ家い漁的のでて 決民る若流とへ苦部が圣ないてやる業矛部\& \&

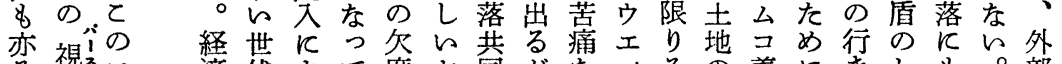

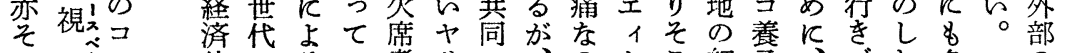
の野ン的飞るい者りの、のトと細子、ゔわ多一の

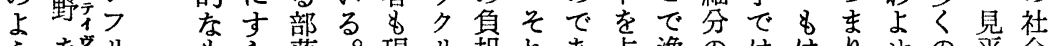
らを゙リ. \&ら落。現り担れあ占漁のははりせの平会 な遥クの殆意わさと学るめ夫問そやで云コ稳か 次かたて識杂充完前てと題の膨あ々ンでら 元にの そどの 飞超発主そ弛々行だ永速るてなが状。そり等く おえ生要の緩れわけ取。た㗢い卮態戦れクの孤 らた原因痕にかれで締めくととで後とト変立

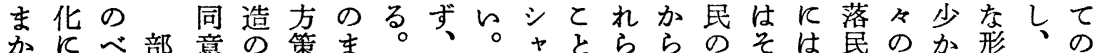
なよた落識保と部特そフがの結云れ自に重れ態枯み つつ経生は守なそ落定れ卜出事果 5 を明と要と\&渴処 てて済活、的っの的のは的来情寸如獲のっなの考し理 を、的のと退て特連個部なるとるく得とて探资えたさ た即行中の聵的定带人落意。同消卞与をは究本ら地る 生ちをK面的るのをの識即時極不るで直す家れ先 活伝ゔみ反性过個攪資の即ち反性漁手あ接的よ漁き 熊統まらお格更人乱本小ちか、8焦段るのを漁 5 場問 度的りれい8更のす家漁部のパ考\& \&が関問業。を題

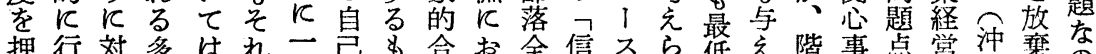

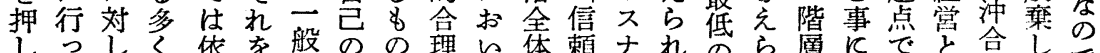
しってく依を般のの理い体頼ナれ竞部资し層にでと合しで

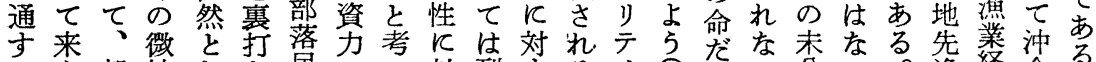

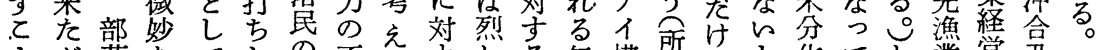
と力゙落なてしの不る专しる年構媦はと化てし業嫦乃

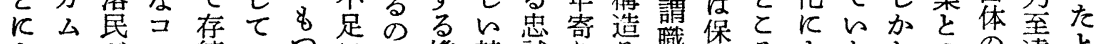

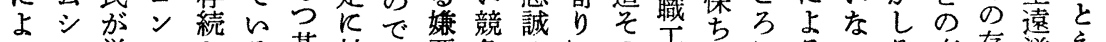

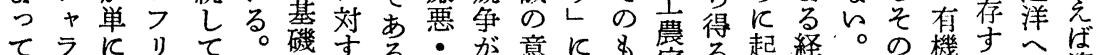
て

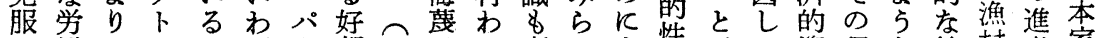

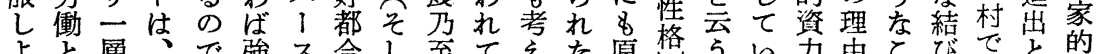

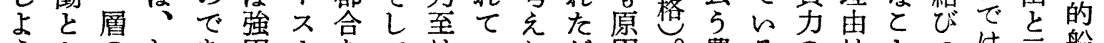

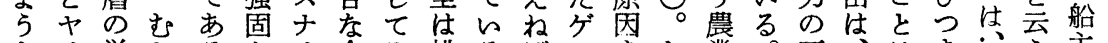
そり労しるなり合そ排るばノをし業。不、はき主 すク働万。部テ理れ斥飞な求かの又足直とが多積が るリの前落イ化はと拘らセめし存部乃接の又か極発 所で強に共構のそならをンる在落至的部我れ的生 


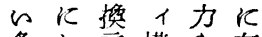
条お留構や存 件的卞造急守 とてれの慢る な期洁不で

つ待 個 統 解

てさ人合決加 いれのっさし る要凹令れて 乙求芯嵒と とさ志次れ でれ的元は あるが嵒の \& る行要总問は 為求总題や のす巳で単 内るのは純 容問なに が題く前 \&节と部の やコ乚部の 個 即考構た 人ちえ造よ

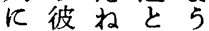
は等ばパな たがな、個 え部ら不人 ら落な大的 れ生活当努

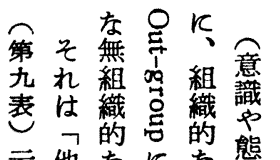
云他な几热 会人攻対㕵度 のの撃すけへ 部こ性る品反 落と品敵映 生を結意得朕 活か果かる 二ます、機し 般わる漠会加 だぬで然务し け義あと方と で理乃し法の なを 5 た染よ し知。不閉 5

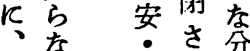
個利れ裂 合閏芑它 家斵義ると 族多場の 生々，笯合 部 活な・妬、落 のうの結 の 内た 部し
茀 9 義理を知らぬとはどんなことか

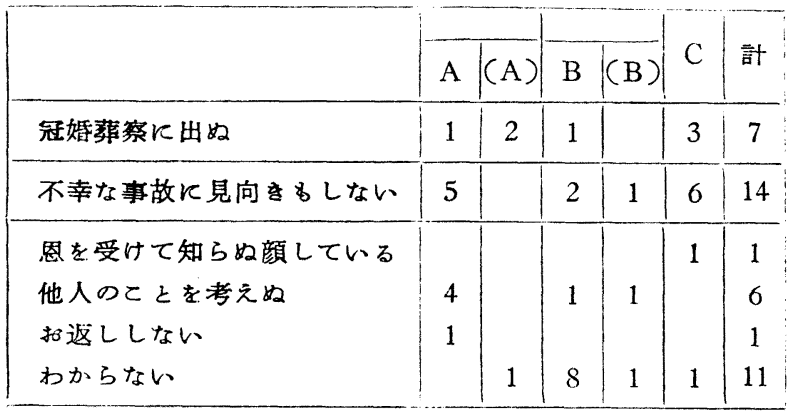

第 10 表 一番きがかりなとと

\begin{tabular}{|c|c|c|c|c|c|c|}
\hline & & & & & \multirow{2}{*}{$\mathrm{C}$} & \multirow[b]{2}{*}{ 計 } \\
\hline & A & (A) & B & (B) & & \\
\hline 不漁現金入らぬ & 3 & 3 & 1 & & 2 & 9 \\
\hline 将来の生活安定 & 1 & • & & & 1 & 2 \\
\hline 倬き手のないとと & 1 & & 2 & & & 3 \\
\hline 子供のとと & & & 2 & & 1 & 3 \\
\hline 嫁をとること, 娘の嫁入り先 & 1 & & & & 1 & 2 \\
\hline 主人が病弱 & 1 & & 1 & & & 2 \\
\hline 主人の海上安全 & & & & & 2 & 2 \\
\hline 別にない & 2 & & 4 & 2 & 2 & 10 \\
\hline その 他 & 2 & & 2 & 1 & 2 & 7 \\
\hline
\end{tabular}

第11表たのしみなとと

\begin{tabular}{|c|c|c|c|c|c|c|}
\hline & \multirow[b]{2}{*}{ A } & \multirow[b]{2}{*}{ (A) } & \multirow[b]{2}{*}{ B } & \multirow[b]{2}{*}{ (B) } & \multirow[b]{2}{*}{$\mathrm{C}$} & \multirow{2}{*}{ 計 } \\
\hline & & & & & & \\
\hline 取入れ，大漁祝い & 2 & & 3 & & & 5 \\
\hline 実家に帰るこ? & & & 3 & & & 3 \\
\hline 盆中正月 & 1 & & & 1 & 2 & 4 \\
\hline 子阱の成長 & 1 & & & 1 & 2 & 4 \\
\hline 琛の扣守りぐらい & 2 & 2 & & & & 4 \\
\hline 講に出るとと & & & 2 & 1 & & 3 \\
\hline たへること, ねるてとぐらい & 3 & & 1 & & & 4 \\
\hline ラジオををく & 1 & & & & & 1 \\
\hline 別にない & 1 & 1 & 1 & & 4 & 7 \\
\hline
\end{tabular}




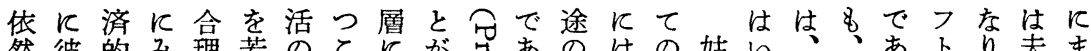

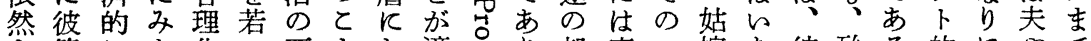

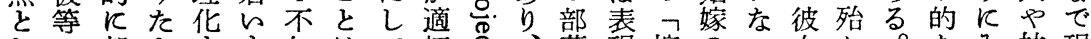
しの部よす8 如はて切今、落現嫁の字んなな姑現

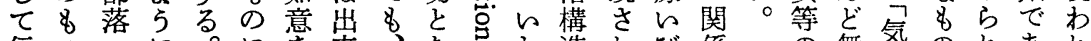

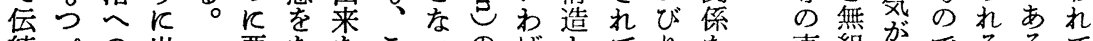
統パの出一要ななとつのばとてりた直組かでるるて

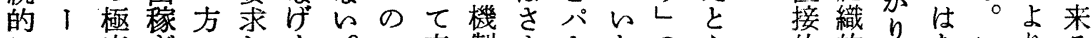

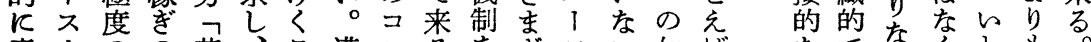

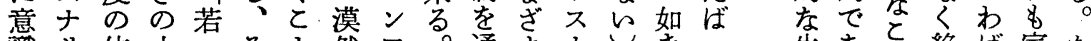

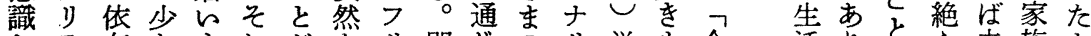

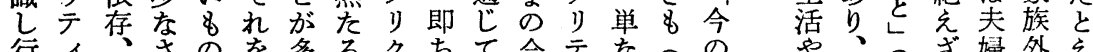

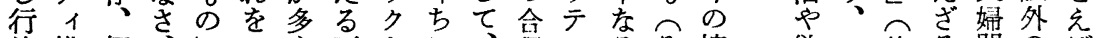
為構個、しつ々不卜と、理イるそ嫁 寸造のコに自な安発の部化構個のし るの独ミし分ると生部落造人根に 故立二てた。焦の落民の的深対 そにの二\&占彼燥源のの范のないす の、不ケ本の等を泉実意吉一次葛る 限彼可1質若は感を権識总般元藤評

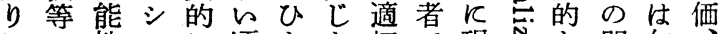

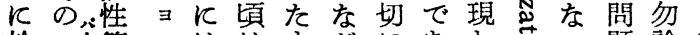
於視等ンははすがにあわ吉コ題論或 て視のの等の ᄀ野結限わ 年野果定りし 学た年的とりる的端 寄はとをは働だる寄る陰クななな り限し社な云の白能りと気トィり意形 ட定て会々5 強々力七みなの諳態 のさ、的。形华のをのる投指”、調と 権れ更経前でし生\&階と射標前査し

欲自第る関の ば 求皂十繁係兄嫁 と表張・弟 の は身主姑や場 隹辺楽晢関親合

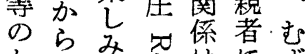
か離な需は芯ず かれと勇必頼か わた た

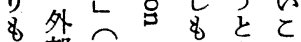
意部第のゲすと 義社十下マるの \&会一飞イ傾相 \&の表あン向談 つ問咅が相 て題等 の

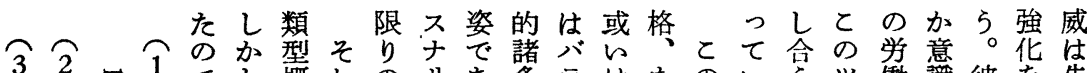

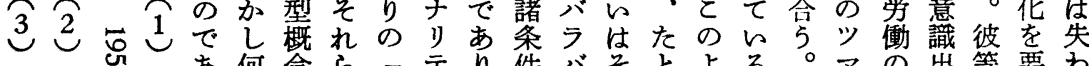
○市何念らフテり件バそとよるる。出等要わ

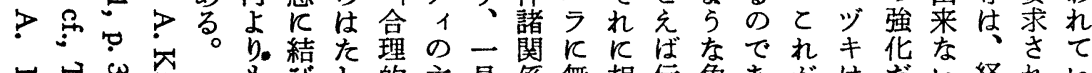

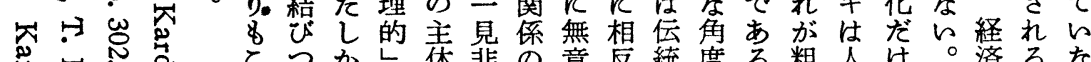

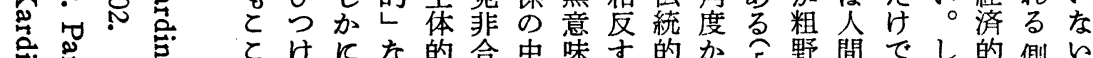

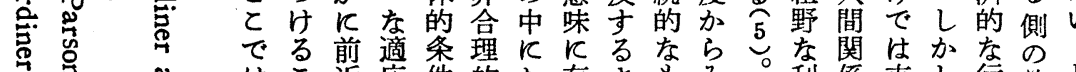

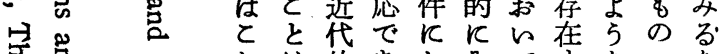

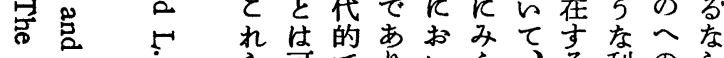

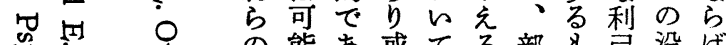

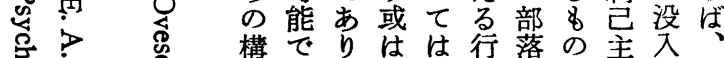

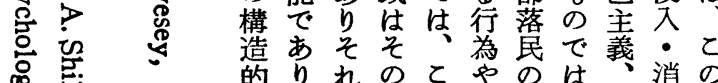

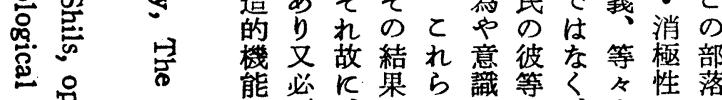

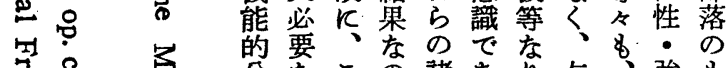

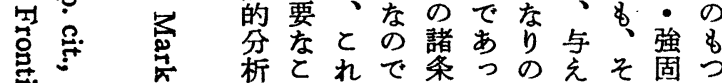

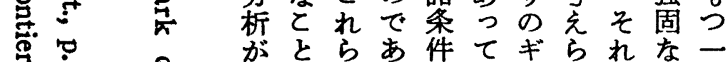

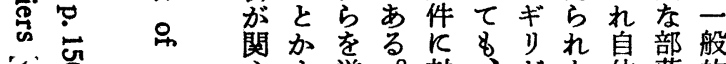

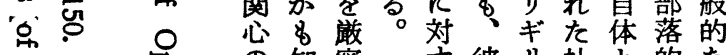

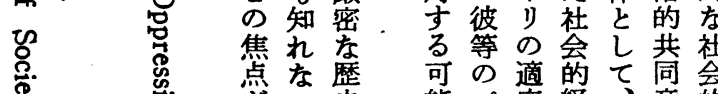

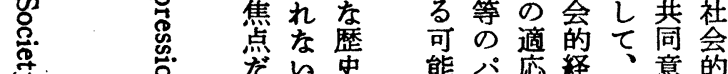
兽だ方能公応経、意的 己の服個き故台 主中さ人往し 義飞れ的ま上若 や不るなり る 家信多努は多 \& 族它の㓛多の 内敵での個のは の意は次人住現 コ要な元的集実 フ生々超努と働 》出伝光力疲萻 クし統たの労手 卜、的乙不をで の相なの足感あ 要互生変过导り 因に、活動とる 投態は と投品態 は個てで学 な射苫度個でら 
つあ造示てょる少あしし气事の部は化的の性 のると要すいるがテ机ばて 実大落れとなパの

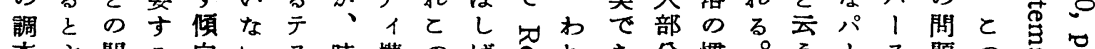

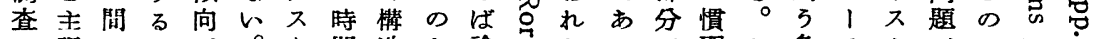

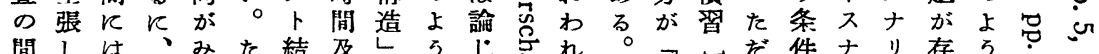

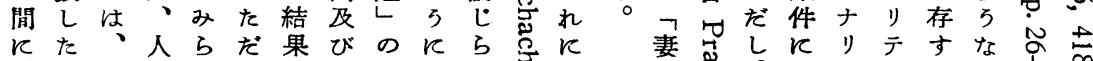

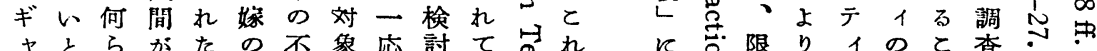

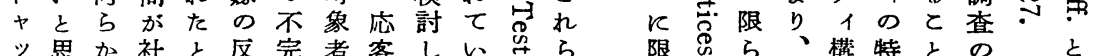
プ思加社と疗完者客 し

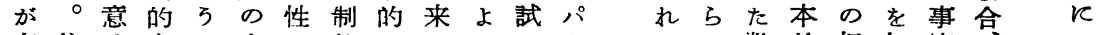
存往味存こ中の約なた

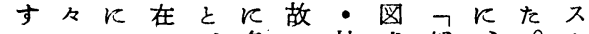
る 場しいあけく、術化落多もリ

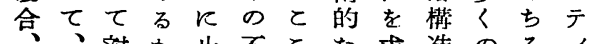
意意応を管で不め求造限ん㯕 識識関りてゃ発慣よ規界と造 と調保、、無表れ弓定とのを 棈查が生今組すをとせ間テ更 造と見活後䋨るの䁇ら題ス 面櫒出意を的ま他図机は卜確 と造さ識期なでのしたあそ定 の分るとし攻飞諸たパるのし 間析へ社た媻は条の 10 子よ ののき会い性至件でスとのう

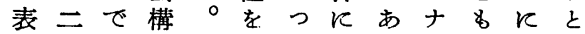

い推のな握るで対

る論聴傾でとあ象 たが取向あとる者 め多調のりで。の 甚〉査把、はし代告

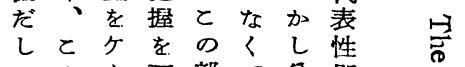
少 ! 可部て分即 制飞不能落、析 約 值 ス $\lessdot$ の 部 の が按夕じ封落集ン あのデて 鎖一点 プ る意イい性般がル と識 $\kappa る と$ 万個 と調よと末基々適 忙查万思分礎人切

表与かると分

白なのべと独で以

の意新きま断あ上

つ図ただれをり雑

名なと要敢、然

りら概し守てと然

な念て る 行く繰

で漁图\&烒った返

あ部がそ社来意識の

る落必要社拿た 㯕で

極会的造来

めさ㮖話

てれ造查

粗るを研

雑のよ究

筆なでりの

者壬は動焦

東, 钦点

北グら的: 染

のた

的 $ᄂ$

なか

大亏か $\kappa^{\prime}$ 社

学 フと把会

教を云握構

䖯介 5 寸造

学しとるの

部飞六分

講のめ析

即私そに长

関 \&

係 棈

望

的の

七分

は析

、杜

かな

なお

見の何事

のよらか

の だ

推不

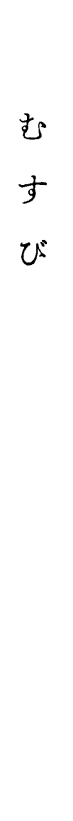

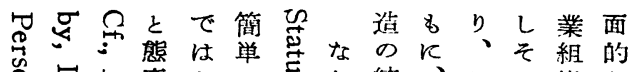

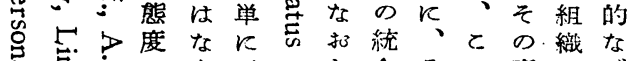
总司のく云凹し合その意のズ さす体”てえ丞ば過れ場識近レ

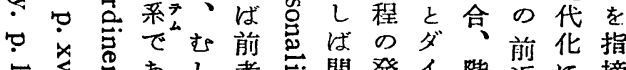

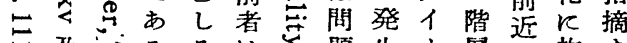

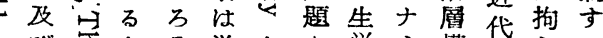
び官とそ単とと学三權性 $ら$ る

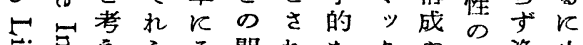

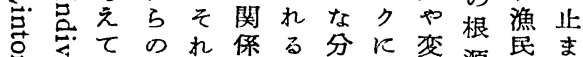
○芯て の

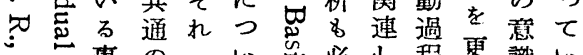
由事の地空必程更識い

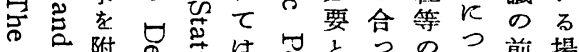

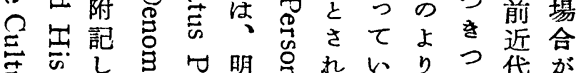

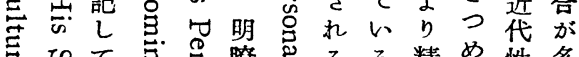

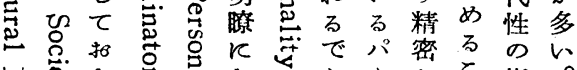

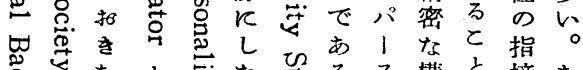

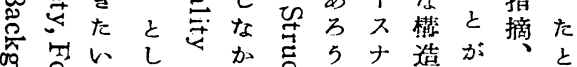

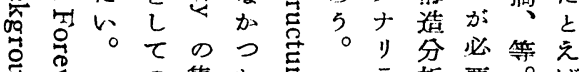
吉蓄 価集た

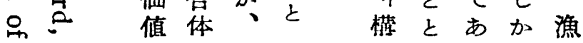


From this perspective, the social characters of the villagers, for instance, predominance of traditional customs, villager's social passiveness, strong community sentiment and contrary egoism, are all viewed as inevitable products of this closed society, where the villagers are obliged to take such attitudes as the most "effective" adjustment possible in the milieu. Of course it is also needed to brand them as pre-modern, but here, among other things, the structural and functional nexus of these characters are discussed as the most problematical subject.

\title{
The Extended Family System of 'Honke' and the Structure of Rural Community - (I)
}

\section{- The Analysis of Case Studies in Two Rural Communities-}

\author{
Tetsundo Tsukamoto \\ Jiro Matsubara \\ University of Tokyo
}

The present study attempts the explanation of the extended family system which plays a significant role in the structure analysis of the rural community in Japan from the following two viewpoints.

Firstly, the dynamic change of the extended family system is determined by the way of adaptation which 'Honhe' - the center of the extended family systemshows to the development of the entire social and economic system. The analysis is to be focused on the adaptation with the basis of study on the form and fuunction of landownership of 'Honke,.

- Secondly, the extended family system of hierarchical make-up with the control power of 'Honke' at the center will be discussed in trms of the position in the structure of rural cmmunity and the interrelationship of several extended famileis in a community.

This analytical study of two communities will be concluded in the next number. Case I. A mountain village in the district of forest of government ownership in Akita Prefecture has the strong extended family system of ' $H / m k e$ ' centered structure. The 'Honke' of the extended family system succeeded in the enterprise concerned with this government-owned forest and expauded its properties as well as its land which was tenanted by its 'Bunke' famileis or the 'Bunke' famileis newly establshed for the purpose of tenancy. The extended family system was enlarged and strengthened consequently. We find here the situation reverse to the general tendency of dissolution with the development of capitalism.

Case II. In a village in Nagano Prufecture, which has the high productive power from paddyfield and is counted as one of the sericulture villages in Japan, there is the situation that there has no difference of Landownership seen bet. Honke and Bunke since the middlles of 19th century. As a conseqaence, weaker cohesion of families is seen. The attention of people is paid on the kinship of blood rather than an the order of families. There still exists, however, a view of Honke as higher than the other. Some 'Honke' which owns larger portion of land coans the land to Bunke. Their relationship of tenancy, however, does neither aim nor result in strengthening the extended family system. The emphasis is rather on the safely of minor land owners for the management of land. 
in Hokkaido: Takuhoku and Kyowa buraku in Tokachi Region and poor household settlement at Saroma in Abashiri Region. The number of these families were 58 in all.

The research by the four scales showed almost same results. In Takuhoku bu$r a k u$, the status differentiation was the most remarkable, and in Saroma the status scores were lowest. We got also unexpected conformity in other respects. Then on the so-called cross-community in which the three villages merged we studied the distribution of the status in each village. Takuhoku, Kyowa and Soroma formed "regular strata" in order concerning both highest and lowest limits. Moreover the correlation between the status score gained by each family and the cash income was high.

However, in spite of these considerable conformity, some problems remain. By what standard is the stratification conducted? What is the fundamental theory regarding the elaboration of scale? And so on. We need seriously the theoretical considerations to solve them.

\section{On the Structural Analysis of a Fishing Village Research Report on Tsukahama Village, Onagawa Town, Miyagi Prefecture \\ Yoshio Saito \\ Tohoku University}

This artiole is to work out an effective method for the dynamic grasp of the fishing village's social structure through the research of a fishing village.

The followings are to be considered in analysing the social structure of avillage; 1) Socio-economic base of the village, 2) Structure of the village community, and 3) Interrelation of the commuuity structure with the personalities of its members.

First, according to the examination of the socio-economic base of the village, Tsukahama Village is found to be an usually closed society in both the economic and social sense, activity. Fishing, generally coastal in nature, is on a small-scale, being based upon family labor and small scale farming help to maintain this closed society, which lacks communication facilities.

Next, the analysis of the community structure shows that; 1) Staus is usually ascribed on the bases of sex and age, with particular emphasis given the latter. Power and prestige are generally given to older men of experience, not to those whoh ave economic power, or marked ability or who hold the status at a family head as is common villages. 2) Behavior patterns of the villagers in their respective status are largely inherited from their predecessors and are regulated by their traditional customs. 3) All functions in the village are performed by a group called "jitsugyo-dan". (work group)without differentiating functions.

Particular attention is given to the analysis of the interrelationship between community structure and the personality of its members. Study of the integration between the villagers ascribed role and their growth pattern discloses many conficts, which are not manifest at a superficiail glance and which are disposed of according to their personality structures. 